\title{
LA RACIONALIDAD IMPERIALISTA EN LA MONUMENTAL OBRA DE JAMES MILL
}

Homero Cuevas*

7 n otras ocasiones he expresado insatisfacción ante los preámbulos parece inevitable en circunstancias como las del presente artículo. Para empezar, constituye el tercero entre once capítulos de un libro titulado La dominación internacional en el análisis económico, a punto de ser terminado. En segundo lugar, su objetivo no es la historia, a pesar de las apariencias y del título que cobija a los seis volúmenes de la obra de James Mill sobre la dominación británica en la India (The history of the British India, 1826). Su propósito es teórico, en la medida en que extrae y explicita algunos elementos que estructuran los procesos de dominación de las potencias capitalistas en la economía internacional. En este sentido, la obra de Mill, no obstante sus defectos y prejuicios respecto de las valoraciones culturales, marcó un hito y legó la base de las teorizaciones posteriores.

\section{EL LUGAR DE LA SOCIEDAD ANÓNIMA}

Los primeros documentos negociables en un mercado de acciones fueron emitidos en 1606 por la Compañía Holandesa de las Indias Orientales (VOC), incorporada en 1602. Entre sus motivaciones y consecuencias sobresalían: a) la concentración de capital en una escala inalcanzable por otros medios; b) la integración en un monopolio de las compañías de Brabante, Rotterdam, Amsterdam y van Herre, que previamente competían entre sí; c) el reemplazo de la monarquía hispano-lusitana en la determinación mayorista de los precios de las

\footnotetext{
* Economista, Profesor Emérito de la Facultad de Economía de la Universidad Externado de Colombia, Bogotá, Colombia [chhcuevas@yahoo.com]. Fecha de recepción: 25 de abril de 2011, fecha de modificación: 4 de mayo de 2011, fecha de aceptación: 6 de mayo de 2011.
} 
especias; d) la asunción comercial de funciones diplomáticas, judiciales y militares, por delegación oficial, para la seguridad en ultramar, la destrucción de competidores, la apropiación de tesoros, la apertura de mercados y para garantizar las condiciones externas exigidas por el monopolio; e) la ampliación de la base de apoyo para tal empresa, vinculando a miles de accionistas y suscriptores de bonos, a las cámaras regionales de comercio con sus socios, a las autoridades como directores y a ochenta mil empleados entre marinos (25\%), militares (12,5\%) y civiles; f) mientras que la tasa de interés caía por debajo del $4 \%$, según algunas estimaciones la VOC obtuvo rentabilidades anuales del 70\% algunas veces y del $18 \%$ en promedio durante doscientos años, hasta su liquidación bajo el peso de una deuda que al final asumió el Estado (Tschöpe, 2008); g) la socialización de tales excedentes mediante el gasto, sin destacar por el momento las ganancias individuales de los empleados, por fuera de los libros de la compañía.

Los comerciantes de los Países Bajos habían sido distribuidores para el Norte de Europa de las especias orientales monopolizadas por los portugueses con la ruta marítima abierta por Vasco de Gama en 1498. Pero en 1591 se les suspendió tal licencia, entre las secuelas de su independencia del Imperio Español. Desde 1595 iniciaron su propio comercio mayorista con el Oriente, desplazando poco a poco a los portugueses mediante mayor eficiencia y acciones de fuerza.

También en 1591, comerciantes ingleses enviaron una expedición, más en misión de piratería contra los portugueses que comercial, según Mill, aunque con resultados desastrosos. Pero al finalizar 1600, una asociación conocida como The Adventurers recibió de la Reina Isabel licencia de incorporación bajo el nombre de "the Governor and Company of Merchants of London, trading to the East Indies", con patente británica de monopolio comercial al oriente del Cabo de Buena Esperanza y hasta el Estrecho de Magallanes.

Con 101 acciones y un comité de 24 directores, sería el origen de la Compañía Inglesa de las Indias Orientales (CIIO). Sin embargo, una parte de los titulares no realizó giros de capital; los restantes agruparon sus inversiones en diversas compañías, como en los negocios anteriores, aunque cubriéndose ahora con una misma patente; y sólo en 1612 se decidió que empezara a funcionar en realidad como una sociedad anónima.

Sobre este cambio, la observación de Mill es significativa: "Si [la situación previa] se adaptaba mejor o peor a la naturaleza del comercio y a los intereses nacionales, en todo caso era menos favorable al poder y a las inclinaciones de un gobernador [de la Compañía] y de 
sus directores que una sociedad anónima (joint-stock), la cual ponía en sus manos la totalidad de la administración y del poder del conglomerado completo" (Mill, 1826, v. I, lib. I, cap. II). El "poder omnímodo" de los directores de la VOC holandesa (Heckscher, 1931, 348) podía encontrar así un reflejo en la compañía inglesa.

Los cuatro viajes realizados entre 1613 y 1616 bajo la nueva modalidad, con una flota de unos siete buques respaldados por casi mil accionistas, arrojaron una rentabilidad del 87\%, mientras que fue el doble en los ocho viajes anteriores. Y hacia 1625 la Compañía declaró su incapacidad para algunos gastos, un preocupante nivel de endeudamiento y una caída en el valor de sus acciones. En 1654, "Las dificultades financieras de la Compañía eran enormes: sus distintas divisiones adeudaban cincuenta mil libras [del momento]; y muchos de sus propietarios estaban en difíciles circunstancias"(ibíd., cap. III). En 1700 las acciones cayeron al 32\% "de su valor" (ibíd., cap. V).

No sorprende, entonces, la reacción entre asociaciones de accionistas, señalando el "carácter ineficiente" de la sociedad anónima, solicitando su disolución y un retorno a los "viajes separados con su gerencia particularizada, lo cual resultaría mucho más rentable, como demostraba la prosperidad de las compañías privadas y abiertas, entre ellas las del comercio con Turquía, Moscú y regiones aledañas" (ibíd., cap. III).

Por el contrario, los directores consideraban imprescindible la fuerza de la sociedad anónima para competir con los poderosos portugueses y holandeses, financiar las enormes inversiones requeridas por ese tráfico, incluyendo ya en ese momento los establecimientos (fuertes con bodegas) en al menos catorce principados, y dar credibilidad a la escala de las garantías ofrecidas ante estos últimos. Es más, dadas sus dificultades para atraer suscripciones frescas de capital, solicitaban estímulos adicionales mediante nuevos privilegios y, "en particular, asistencia suficiente para recuperar [de los holandeses] y retener las Islas de las Especias" (ibíd.).

Esta dialéctica, que llegó a encarnarse en empresas alternativas con licencia oficial, como la organizada por Endymion Porter con el propio rey como accionista, como The Merchant Adventurers o como recurrentes compañías separadas dentro de la original Merchants of London, terminó en 1702, cuando todas las inversiones competidoras quedaron efectivamente monopolizadas bajo "The United Company of Merchants Trading to the East Indies" (ibíd., cap. V); a lo cual añadía la Compañía sus facultades legales para procesar como piratas y aplicarles la pena capital a los comerciantes independientes que se atrevieran a competirle dentro de sus dominios patentados. 
A pesar de todo, “En 1732 la Compañía se vio obligada a disminuir sus dividendos anuales del $8 \%$ al $7 \%$, hasta 1744 , cuando volvieron al 8\%. La Compañía holandesa distribuyó anualmente el 25\% de 1730 a 1735 ; el $20 \%$ en 1736 ; el $15 \%$ hasta 1739 ; el $12,5 \%$ hasta 1743 y el $15 \%$ en 1744” (lib. IV, cap. I). Para 1780, “las finanzas de la Compañía en todos los sitios de la India se habían convertido en una fuente de malestar [...] Aun Bengala misma, aunque había gozado de completa tranquilidad [...] estaba tan exhausta que el Consejo Supremo quedó reducido otra vez al expediente de emitir deuda" (lib. V, cap. VI). Es más, ante el examen de Mill recurrían en la Compañía inglesa su contabilidad equívoca y su inclinación a emitir deuda para la distribución de dividendos. Por ejemplo: en 1766 "se demandó inoportunamente otro aumento de dividendos [...] que habían sido ya elevados del seis al diez por ciento, multiplicando el número de accionistas y haciendo crecer el capital al 263\% [...] En vano expusieron los directores el alto endeudamiento de la Compañía; y señalaron la imprudencia de dividendos aumentados, cuando para girarlos se requerían préstamos con pesados intereses. En una asamblea general, un dividendo de doce y medio por ciento fue aprobado para ese año (1767)" (lib. IV, cap. VII). Y en 1787, "Las finanzas de la Compañía se encontraban en su estado usual de presión extrema y frustración” (lib. VI, cap. I).

Hizo eco Mill, entonces, a la opinión convencional así: "Con respecto a la competencia comercial, la habilidad y vigilancia de los individuos operando para su propio interés era seguramente un instrumento más poderoso que la imbecilidad y la negligencia de la administración en una sociedad anónima. Y, en lo referente a la competencia bélica, unos pocos buques de guerra, con unas pocas compañías de marines, empleados por el gobierno, hubieran rendido mucha más seguridad que todos los esfuerzos posibles de una apocada sociedad anónima" (lib. I, cap. III).

(Hacia 1665 la flota de la Compañía ya sumaba unos treinta buques descritos como "comerciales de guerra", warlike mercantil ships, con entre sesenta y cien tripulantes cada uno).

Sin embargo, era otra sociedad anónima exitosa (la VOC), “con un capital más poderoso", la que había repelido de las islas a la Compañía inglesa, obligándola a buscar nuevos horizontes en el subcontinente de la India. Además, la separación de las inversiones comerciales y las militares sugería complicaciones. Por una parte podía reducir los costos, pero por la otra interponía obstáculos políticos y administrativos entre los objetivos de la Compañía y la movilización armada para alcanzarlos. 
En cualquier caso, con el permanente desencanto sobre las "infladas expectativas de rentabilidad" accionaria, la persistencia en la Compañía inglesa apuntaba en parte hacia intereses más profundos.

\section{RENTAS EFECTIVAS BAJO LA FORMALIDAD CONTABLE}

Un viaje redondo a la India y la comunicación podían tomar más de un año, a lo cual se añadía la ignorancia del idioma, las leyes y las costumbres. "Los directores ignoraban las circunstancias locales y con frecuencia transmitían instrucciones cuya ejecución resultaba altamente imprudente. Sus subalternos en el exterior tenían, entonces, buenas razones para omitirlas. Por lo tanto, con una puerta abierta para su conducta discrecional, las órdenes de los directores eran naturalmente desobedecidas, con la misma frecuencia para el beneficio de los funcionarios en el extranjero que para el beneficio de la Compañía en Inglaterra" (lib. IV, cap. IV).

A través de dicha puerta fluyeron, entonces, los negocios particulares de los funcionarios. Primero: se apoderaron del comercio interno, desplazando a los nativos. La Compañía procuraba limitarse a los procedimientos "rutinarios" de las transacciones mayores en el comercio exterior, concentradas en sus factories (o bodegas) con subastas y acopios entre intermediarios más pequeños, para eludir "un trabajo de infinito detalle que empleaba a una multitud de agentes" (cinco intermediarios con especialidades distintas eran requeridos entre un tejedor indio y una bodega de la Compañía). También disminuía de esa manera sus costos de seguridad en el transporte y el cuidado de las mercancías. Pero sus funcionarios locales pudieron emplear su capacidad de decisión, su conocimiento de los procedimientos, su propio dinero y el aparato militar de la Compañía para controlar la cadena y explotar un monopsonio que "obliga a los artesanos a aceptar quince o veinte, $y$ con frecuencia treinta o cuarenta por ciento menos de lo que valdría su producto en el mercado [...] Mucha colusión y trucos, mucho fraude contra la Compañía y mucha opresión contra los tejedores surge de la oscuridad entre tanta complicación" (ibíd.).

En el comercio de contravía, imponían en sus negocios personales, con apoyo del presidente de la Compañía en Bengala, las exenciones de impuestos y de inspecciones aduaneras obtenidas para las importaciones específicas de aquella, entronizando un contrabando "destructivo tributariamente y ruinoso para los comerciantes nativos, sobre quienes recaían altos aranceles". En 1765, "la exacción de opresivos impuestos, 
de los cuales estaban exentos los ingleses, equivalía a una prohibición de cualquier otra clase de comerciantes" (ibíd., lib. IV, cap. VII).

Segundo: el monopolio de la sal para los ingleses, pagando un impuesto del 2,5\%, había sido obtenido del nabab de Bengala en 1758 por Robert Clive (lib. IV, cap. V). Y cuando éste regresó a la India como gobernador por segunda vez, en 1764, la usurpación por los empleados había llegado a ser tan escandalosa que los directores de la Compañía concluían: "Las enormes fortunas adquiridas en el comercio interior han sido obtenidas mediante escenas de la conducta más tiránica y opresiva que se haya conocido jamás en cualquier época o país" (carta citada en lib. IV, cap. VII). Y transmitían una orden "prohibiendo completamente el comercio interior de sus funcionarios". Como respuesta, "Clive y [...] otros miembros del Comité Selecto [...] formaron una sociedad [...] para comprar grandes cantidades de sal [...] y en nueve meses realizaron un beneficio del 49\% [...] Para excusar a Clive se argumentaba que el propósito había sido hacer una fortuna para tres caballeros que a su servicio venían de Inglaterra (por primera vez), incluyendo a su cirujano" (ibíd., cap. VI).

Ante la insistencia de los directores, los funcionarios simularon obediencia renunciando al comercio de tabaco, que era insignificante, mientras "El Comité Selecto decidió que debería organizarse un monopolio (usufructuado por una sociedad privada de los altos empleados) para el comercio de la sal". En un memorando, Clive argumentaba que los directores "no podían tener siquiera la menor idea del cambio favorable para los negocios de estas provincias, donde los intereses del nabab sobre la sal han dejado de ser relevantes". Sin embargo, reconocía que "La súbita y en muchos casos injustificable adquisición de riqueza había dado lugar al lujo en todas las formas y en sus más perniciosos excesos [...] infectando a casi todos los miembros de cada departamento [...] Cualquier empleado inferior parecía tan familiarizado con la riqueza [...] que desapareció toda distinción con sus superiores" (citado en lib. IV, cap. VII).

Se señalaban, además, los horarios sustraídos a la Compañía, la competencia con sus propios funcionarios en algunos casos y el afán de los más experimentados por regresar con sus súbitas riquezas a Inglaterra. Con tales argumentos, y para disminuir la anarquía en la explotación del comercio interior, Clive formalizó, dentro de la misma Compañía, otra "sociedad comercial para el beneficio [exclusivo] de los funcionarios superiores de la Compañía [...] Deduciendo un derecho para esta, estimado en cien mil libras anuales, las ganancias 
se dividirían así: para un primera clase de propietarios, 35 acciones ( 5 para el gobernador; 3 para el general; 3 para el segundo en el Comité; 2 para cada uno de sus otros miembros); para una segunda clase, 12 acciones (divididas entre un capitán, tres tenientes coroneles y catorce funcionarios senior); para la tercera clase, 9 acciones (divididas entre trece factors, o inmediatos bajo los senior, cuatro mayores, seis cirujanos, el secretario del Comité, un contador, un traductor y un subdirector de bodegas)" (ibíd., lib. IV, cap. VII).

Los directores declararon ilegal su "admirable arreglo" (en las irónicas palabras de Mill) y amenazaron con procesarlo junto a los demás socios. Después de esto, Clive regresó a Inglaterra "por razones de salud" y tal sociedad fue disuelta formalmente, pero continuó usufructuando durante otro año los contratos vigentes, hasta 1768 (lib. IV, cap. VII). Sería ingenuo creer que la creatividad para explotar las ventajas dejaría de florecer en múltiples formas.

Tercero: "Uno de los negocios principales [de los funcionarios británicos] en esos territorios consistía en los préstamos de dinero". Como ilustración paradigmática, "El señor Paul Benfield, un empleado en uno de los niveles más bajos del departamento civil de la Compañía, que se había ocupado paralelamente de funciones más lucrativas que las de sus deberes como oficinista, convirtiéndose no sólo en un favorito del nabab sino en el principal agente de préstamos de dinero [...] se declaró acreedor [en 1775] de la inmensa suma de 234 mil libras esterlinas [de la época; 162 mil adeudadas por el nabab; 72 mil adeudadas por particulares] [...] prestadas por un funcionario junior de la Compañía, con un salario de unos pocos de cientos de libras anuales" (ibíd., lib. V, cap. IV).

Las exportaciones inglesas de metálico a Oriente constituían un privilegio legal de la Compañía que excluía a sus funcionarios en calidad de particulares. Y operaba con restricciones tan apretadas que hacía endeudar a sus agencias en la India con tasas anuales de interés de1 9\%, mientras podía obtener fondos al 4\% en Inglaterra (lib. I, cap. IV, nota 6). Inclusive, algunas veces forzaban en Calcuta, Bombay o Madrás desvíos de la liquidez destinada al comercio con China.

Podría pensarse, por supuesto, que los funcionarios tomaban fiadas parte de sus importaciones particulares de Inglaterra, para colocarlas a crédito en la India, explotando el diferencial de tasas de interés además del margen comercial. Por añadidura, actuaban como prestamistas de la Compañía, usándola en el mismo acto como vehículo de sus remesas a casa. De ese modo, contra letras de cambio redimibles en Londres, depositaban fondos en las subsidiarias de la India. 
Sus beneficios particulares, sin embargo, excedían "en mucho" al superávit en la balanza comercial de la Compañía. Esta, por lo tanto, se veía forzada a limitar la emisión de letras, rechazando fondos que sus propios funcionarios colocaban, con el mismo procedimiento, en las compañías holandesa y francesa para las Indias Orientales. Los más peligrosos competidores y enemigos terminaban financiados, así, por los negocios de los empleados de la Compañía inglesa.

De todas maneras, las dudas sobre la certeza, el origen y la legitimidad de las acreencias de los funcionarios británicos en la India, las cuales generaron investigaciones legales, como en el caso de Benfield, sólo indicaban que, además de la usurpación del comercio interno, el contrabando, la sal y los préstamos, disponían de otras fuentes cruciales para su veloz enriquecimiento.

Cuarto: regalos y extorsiones. "Los obsequios del nabab y otros jefes del país, algunas veces de muy alto valor, a los cuales se han habituado los funcionarios (de la Compañía) desde que adquirieron ascendencia en el gobierno, atrajeron la atención [en Londres] [...] Además de las sumas que pudieron ser ocultadas, cuya estimación resultaría difícil, en 1773 ante la Cámara de los Comunes 'se demostraron o reconocieron regalos de los príncipes y otros nativos de Bengala, entre 1757 y 1766 [...] por un total de 5.940.498 libras esterlinas [...] excluyendo el jaghire de Lord Clive"'(ibíd., lib. IV, cap. V). En la lista aparecían el gobernador Drake, el comandante en jefe, miembros del Comité Selecto y del Consejo Directivo, oficiales de las fuerzas armadas y una serie de otros funcionarios.

Clive explicó: "En un país con abundante dinero, donde el miedo es la base del gobierno y donde nuestras armas son siempre victoriosas, no sorprende que el ansia de riquezas encuentre con rapidez los medios para satisfacerse o que los instrumentos del poder se respalden en su autoridad y procedan aun a la extorsión cuando la simple corrupción resulta insuficiente ante su rapacidad. Era inevitable que estos ejemplos de los superiores fueran seguidos por los inferiores en un grado proporcional" (carta citada en ibíd., cap. VII).

Dadas las dimensiones financieras y geopolíticas, pues se sospechaba de colusiones entre líderes nativos y funcionarios, burlando directrices del gobierno británico y de la Compañía, esta ordenó transferirle los obsequios mayores a cuatro mil rupias que llegaren a ser recibidos a partir de mayo de 1764; entre los restantes, los mayores a mil rupias requerirían del consentimiento del Consejo para quedar en manos de los empleados. Mill concluyó que así "la Honorable Compañía se reservaba un poder aun ilimitado para recibir o extorsionar obsequios en su propio beneficio". 
De otro lado, ya había destacado las dificultades para los controles remotos. Como casos notables se supo que, después de tal prohibición, Clive como gobernador había aceptado un obsequio del nabab de Bengala por unas cincuenta mil libras esterlinas. En un comienzo procuró disculparlas como una herencia y finalmente la Compañía accedió al argumento de que estaban destinadas para un fondo de oficiales minusválidos, el cual fue en efecto creado (ibíd.). De otro lado, en 1782 "el gobernador Hastings aceptó del nabab de Chunar un obsequio de 100.000 libras", sin registro contable y objeto también de confusas explicaciones (lib. V, cap. VIII).

Para completar, observó Verelst, quien tuvo conocimiento presencial de algunos procesos: "Mahomed Reza Khan afirma que los regalos no fueron voluntarios, lo cual es negado por los caballeros ingleses. Dado el poder alcanzado por los británicos, quizá el lector podría considerar esto como una disputa semántica" (citado en ibíd., lib. IV, cap. VII, nota 5).

Quinto: arrendamientos. Mill anotó que "En la India el land holder paga nueve décimos del producto al gobierno" (lib. V, cap. III), aunque señaló en otros pasajes tres quintas partes de la producción bruta (lib. VI, cap. V). Pudo referirse con la primera estimación a los ryots, trabajadores directos mantenidos al "mínimo indispensable para su subsistencia" por los zemindars, recaudadores, o al margen de estos últimos sobre el producto, pues ambos agentes eran ancestralmente land holders, de acuerdo con su crítica a los "prejuicios aristocráticos" que imaginaban un "feudalismo" indio y pretendían ensillarlo con un sistema idéntico al de la agricultura británica. En cualquier caso, una conexión tan clara entre esta inmensa masa de rentas y el control político no podía menos que tentar la avaricia de los británicos.

No obstante, ante el objetivo se interponían guerras, numerosos niveles burocráticos entre los productores y el Soberano, con sus respectivas participaciones en la compleja administración del recaudo, y milenarias inercias sobre la organización social y la posesión de hecho. Entre sus primeras experiencias la Compañía intentó, pues, simplificar desde la raíz, sometiendo a subasta pública el arrendamiento de los territorios agrícolas bajo su control; con la prohibición expresa de que en el negocio y en la puja entraran sus propios funcionarios. Pero la creatividad, claro está, no descansaría ante las nuevas oportunidades.

Como ejemplos significativos, el coronel Hannay arrendaba "una gran parte del país" de Oude, bajo licencia de los directivos locales de la Compañía para emplearse temporalmente al servicio del nabab. 
Así, entre 1778 y 1781 obtuvo una fortuna estimada en 300.000 libras (lib. V, cap. VIII). Y, según una de las acusaciones en la Cámara de los Comunes contra el gobernador Warren Hastings, este "colocó en una situación de confianza y poder a un nativo [...] de manera impropia y para fines corruptos; es decir, para explotar las rentas de un gran distrito del país" (lib. VI, cap. II). De paso, los métodos de Deby Sing contra sus subarrendatarios ganaron protagonismo debido a sus escandalosas atrocidades.

Sexto: por último, estaban las compras con las oportunidades de las guerras. "Entre los cargos criminales contra el gobernador general Hastings fueron incluidos [...] contratos para la provisión del ejército con maíz, bueyes y la alimentación de los elefantes, así como para el opio comercializado por la Compañía" (ibíd., cap. I, nota 35). Como un indicador de la escala, durante uno solo de tales conflictos, el ejército perdió cuarenta mil bueyes (ibíd., cap. IV).

La Compañía había aceptado, a pesar de su rechazo del "admirable arreglo" de Clive, "el argumento de que al cortarle a sus funcionarios las fuentes irregulares de ingreso, este no era lo suficientemente opulento" (lib. IV, cap. VII). Y, por tanto, había garantizado simultáneamente (1767) una comisión del $2 \frac{1}{2} \%$ sobre el producto neto de los ingresos territoriales, dividida en 100 acciones con la siguiente distribución: 31 para el gobernador; 7,5 para el comandante en jefe; 2,5 para cada coronel; 1,5 para cada teniente coronel; 0,75 para cada mayor y el resto para los miembros del Consejo Directivo local. Además, se incrementaron las asignaciones por día de actividad para los demás oficiales y suboficiales.

Quedaba formalizado así un estímulo para la iniciativa empresarial dentro de los límites de la Compañía misma y, claro está, para las expansiones territoriales que prometieran recaudos netos. Pero sobre la ineficacia de tales incentivos para contener los abusos, en ausencia de medidas complementarias, Mill sentenció: "Si, como Clive y su Comité afirmaban, los empleados estaban en capacidad y en disposición de saquear y desfalcar cuando eran pequeños sus ingresos, el mero aumento de estos sólo incrementaría su poder y haría poco para modificar sus inclinaciones" (ibíd.).

\section{EL NEXO POLÍTICO DE LAS RENTAS ESPECIALES}

A comienzos del siglo XVII, las empresas de comercio exterior requerían en Inglaterra cartas de privilegio real, al menos por tres razones: la necesidad de exportar bullón; la legalización del uso de sus armas para proteger sus cargamentos contra riesgos inminentes, proviniesen de 
piratas, competidores con rutas patentadas en otros países o rechazos por débiles autoridades ultramarinas; y limitación de la competencia como compensación por una mayor incertidumbre.

Este soporte político común fue trascendido, sin embargo, por algunas peculiaridades de la CIIO: como sociedad anónima, replicaba una base democrática aunque con una dirección oligárquica (connatural a estas organizaciones, según Mill); adquirió funciones gubernamentales junto con las comerciales, y sus actividades, estructura, dimensiones y oportunidades la convirtieron en la principal fuente de clientelismo dentro del sistema político británico.

Los síntomas aparecieron desde el comienzo, cuando Sir Thomas Roe concluía en 1614 que el personal de la Compañía en el exterior era excesivo y su selección inadecuada; mientras el rey y el Duque de Buckingham reclamaban, en 1622, derechos de la Corona y del Almirantazgo sobre las ganancias de la Compañía en el saqueo de la Isla de Ormus, adelantado en conjunto con los persas. El duque transó por 10.000 libras esterlinas, aunque se desconoce el acuerdo con el rey (lib. I, cap. II). En 1625, "Sir Robert Shirley, quien había sido embajador ante la corte de Persia, solicitó al rey y a su Consejo ordenar a la Compañía pagarle 20.000 libras como compensación por sus tareas y servicios para procurarles una apertura comercial". Así mismo, en 1642, el rey "compró al fiado las existencias de pimienta de la Compañía y las revendió a menor precio para conseguir liquidez inmediata”. Parte de la deuda jamás se pagó (ibíd.).

De otro lado, en 1648, "cuando el poder del Parlamento era supremo, y el rey era prisionero en la Isla de Wight, una nueva suscripción [accionaria] fue abierta [por la Compañía], y una política muy obvia fue seguida para lograr que el mayor número posible de miembros del Parlamento se convirtieran en accionistas" (ibíd., cap. III). Entre los esfuerzos para dicho fin se les concedió un plazo extraordinario. En el mismo escenario, cuando logró forzar a los holandeses a un tratado de paz, en 1654, Cromwell pidió prestadas las 85.000 libras que como indemnización recibió la Compañía. Esta expuso sus difíciles circunstancias financieras pero añadió que, más allá de las revoluciones políticas y de los regímenes antagónicos, "en gratitud al protector se sacrificaría girándole 50.000 libras pagaderas a plazos en dieciocho meses" (ibíd.).

Con la restauración monárquica de Carlos II, la carta de privilegios de la Compañía fue renovada y ampliada en 1661, "recibiendo autoridad para hacer la paz y la guerra con cualquier príncipe o nación distintos de los Cristianos [...] Así, junto con el derecho de adminis- 
trar justicia (en ultramar) se le conferían a la Compañía casi todos los poderes de un gobierno" (lib. I, cap. IV). Además, recibida por Carlos como dote de la Infanta Catalina, la Isla de Bombay, con mayores gastos que recaudos, fue ofrecida en administración a la Compañía. Tras un rechazo inicial, ésta la aceptó en 1668 por un arrendamiento nominal de 10 libras anuales, "con todos los poderes políticos para gobernarla”. Y en 1673, la Isla de Santa Helena, recapturada de los holandeses, fue de forma similar cedida a la Compañía mediante una carta real. Esto, por supuesto, potenciaba la espiral entre los nexos políticos y las rentas especiales.

La reforzada amalgama se ilustró con la insurrección de las tropas y la población de Bombay en 1685, "exigiendo la renuncia de la Compañía al gobierno y proclamando la Soberanía del rey”, quien liquidó la rebelión delegando su autoridad en Sir Thomas Grantham, el comandante de la flota de la Compañía. En ese mismo año, esta tomó la decisión de mejorar su posición en Bengala mediante "el envío a la India de un equipo militar sin precedentes" y, profundizando la política de colaboración, para el mismo proyecto le "solicitó al rey una compañía de infantería completa con sus oficiales".

Con ínfimos pretextos, las hostilidades no tardaron en comenzar; pero la Compañía "pagó muy cara su prematura ambición", pues sus factorías fueron ocupadas por las tropas de Aurengzebe, quien “ordenó expulsarla de sus dominios”. Sin embargo, en un trágico error de cálculo, la restauró a su situación anterior después de que "los ingleses se arrodillaron en la más abyecta sumisión" (ibíd., lib. I, cap. V). De esta manera "cultivaron el favor de los mogoles" en una etapa de conquista disimulada, caracterizada por concesiones y compras de asentamientos, como Chuttanuttee, Govindpore, el puerto de Tegnapatam (más tarde Fuerte San David) y Calcuta, iniciando fortificaciones "cautelosamente para no alarmar al gobierno nativo".

De hecho, en 1689 el directorio de la Compañía formalizó sus instrucciones a los funcionarios para la conquista territorial, con la siguiente lógica: "El aumento de nuestras rentas es tan importante como nuestro comercio [...] el cual puede ser interrumpido por muchos eventos [...] esto justifica mantener la fuerza que nos convertirá en una nación en la India [...] en caso contrario seremos uno más entre la masa dispersa de comerciantes casuales, unidos sólo por la carta de privilegio real, capaces de comerciar únicamente donde nadie que tenga poder esté interesado en impedírnoslo. Por estas razones, la sabiduría de los holandeses, como hemos visto, aconseja escribir diez parágrafos acerca del gobierno, de su política militar y civil, de 
la guerra, y del incremento en sus rentas, por cada parágrafo sobre el comercio" (correspondencia citada en ibíd., lib. I, cap. V).

En ese momento había llegado a tal desgreño la parte comercial de la Compañía que esta desarrollaba "un comercio sin ganancia" y "no podía persistir en el incremento del clientelismo sin ruinosas consecuencias" (ibíd.). Por lo pronto, se vio forzada a ordenar el empleo de comerciantes nativos, especialmente de origen armenio, "en vez de multiplicar sus agentes europeos en la India".

Por otra parte, se investigaban indicios de que las deudas de la Compañía excedían al total de sus activos, lo cual precipitó una legislación para prevenir tales ocurrencias en el futuro.

Los comerciantes ingleses excluidos por el monopolio aprovecharon las acusaciones de ineficiencia para demandar un replanteamiento. Además, en el plano político, se cuestionaba ahora la legitimidad de "una patente real sin sanción parlamentaria". Y la Compañía empeoró su defensa presentando sus posesiones territoriales en ultramar como un hecho contradictorio con cualquier propuesta para despojarla de su patente, a pesar de que esta tenía un período fijo, si bien renovable según los resultados. Tal argumento fue atacado como "una burla a la voluntad legislativa de la nación".

Parecía sintomática la identificación de "Asociación Londinense" para la Compañía existente y la de "Asociación general" o "Compañía inglesa" para los nuevos rivales. Y también era significativo el campo de la confrontación final: la primera le ofreció al gobierno un préstamo por 700.000 libras al $4 \%$ de interés anual si se mantenían sus privilegios, con la respectiva aprobación del Parlamento, mientras la última le ofreció dos millones de libras al $8 \%$ si el monopolio le era transferido. En definitiva, el Parlamento dejó sin piso una renovada patente del rey para la vieja Compañía, quedándole tres años de plazo, hasta 1701, para finalizar su comercio con la India; y autorizó a la nueva asociación para iniciar sus operaciones de forma inmediata, con una patente por trece años. En el lapso de traslapo siguieron episodios de confrontación entre las dos compañías pero, como se ha indicado, finalizaron en 1702, cuando se fundieron en un monopolio más poderoso bajo la denominación de "The United Company of Merchants Trading to the East Indies". Además de los dos millones, "Un préstamo de 1.200.000 libras sin intereses fue extraído de las dos compañías para uso del gobierno" (lib. I, cap. V), mientras la patente era extendida hasta 1729 , cuando podría ser renovada, con noticia previa de tres años, según los resultados. 
En 1730, en contra de las propuestas de otras asociaciones, incluida una de apertura para todos los comerciantes británicos, como operaba para África, la excluyente patente de la Compañía fue extendida hasta 1766, y en 1744 hasta 1780 . En el primer caso le donó 200.000 libras al tesoro público, mientras en el otro le otorgó al gobierno un crédito, sin intereses, por un millón de libras que no tenía. Entonces, se legisló para permitir una emisión pública de bonos de la Compañía por dicha suma.

En consecuencia, la nueva cobertura no debilitaba la consistencia de la vieja amalgama; más bien otros factores entrarían a dinamizar la combinación operativa entre la Compañía y el gobierno británico, en primera instancia como un escalamiento de los preparativos militares. De un lado, las autoridades nativas de Bengala, sin oponerse abiertamente, obstaculizaban la venta de 31 municipios concedida en 1717 por el emperador mogol a los ingleses. De otro lado, en 1744 se declaró la guerra entre Francia e Inglaterra, y en 1746 una flota francesa fondeó a cuatro leguas de Madrás y después de algunas batallas tomó esta base centenaria de los ingleses.

La Compañía Francesa de las Indias Orientales (CFIO), cuyos negocios también eran adelantados mediante warlike mercantile ships en los mismos mercados de la CIIO, había sido creada bajo la influencia de Colbert desde 1664. "Mucho más pobre que la Compañía inglesa”, a su vez "mucho más pobre que la holandesa”, la CFIO no parecía una seria amenaza durante los primeros decenios, aparte de que existía un acomodamiento político entre los dos países. Pero en las nuevas condiciones, bajo la dirección del gobernador de la Isla de Francia, la Isla de Bourbon y Pondicherry, el gobierno francés y la CFIO pusieron en acción un plan para salir de su situación residual, eliminar las amenazas de expulsión de la India y, en cambio, expulsar a los ingleses.

Por su parte, "Ante los desastres de la nación en la India, y con celos del poder ganado por los Franceses, el gobierno de Inglaterra había preparado ahora un formidable armamento para el Oriente. Nueve buques de la armada nacional [...] y once de la Compañía para el transporte de tropas y logística [...] zarparon de Inglaterra a fines de 1747 " (lib. IV, cap. I).

En el proceso, completado con guerras de los gobernantes indios entre sí, contra los extranjeros y con toda clase de coaliciones oportunistas, "Los Franceses rompieron el encanto de la timorata opinión [...] de que los Moros eran un bravo y formidable enemigo [...] derrotando un ejército completo con un solo batallón" (Orme, citado 
en ibíd., nota 51). También mostraron cómo los nativos podían ser entrenados en la disciplina de los militares europeos y bajo el mando de estos ser utilizados contra las autoridades de su propio país (sepoys). Con tales lecciones, concluyó Mill, los británicos pudieron encontrar una vía de conquista acelerada.

Así, con el triunfo de la coalición inglesa que depuso al nabab Suraja Dowla e instaló en su lugar a Meer Jaffier, desde 1757 "todas las factorías y posesiones francesas se deberían expropiar; y los franceses se deberían excluir para siempre de Bengala"(lib. IV, cap. III). Después de 1760 , con la rendición de Pondicherry y Gengee, "los franceses quedarían sin puesto militar alguno en la India" (ibíd., cap. IV).

Durante unas negociaciones de paz en 1754, "El ministerio inglés prudentemente despachó una considerable flota a la India”, mientras los representantes de la CFIO y del gobierno francés en Londres “cordialmente cedían" las ventajas logradas gracias a la recursividad local de Labourdonnais, Dupleix y Lally, las cuales tenían en punto de expulsión a los británicos (ibíd., cap. II).

En 1756, con "un plan diseñado en Inglaterra [...] para la expulsión de los franceses", el gobierno británico envió a Bengala bajo las órdenes de Clive tres compañías de artillería y varios centenares de infantes, los cuales fueron reforzados para la retoma de Calcuta por cinco buques de guerra de la armada real bajo el mando del almirante Watson, apoyados con cinco buques de la Compañía. Luego se unirían con la flota real disponible en Madrás bajo el comando del almirante Poncocke. Y mientras "los ingleses disponían de abundante dinero y suministros [...] nada podría exceder el sufrimiento de los franceses por falta de provisiones [...] los británicos con poderosos refuerzos desde Inglaterra [...] sus antagonistas abandonados bajo la indiferencia de su patria" (ibíd., cap. IV).

La recuperación de las posesiones de la Compañía se debía, pues, al gasto público y a la armada nacional. Y, como si esto fuese poco, su adición de control territorial sobre Bengala, con treinta millones de habitantes, Bahar y Orissa, reconocido por decreto imperial de Shah Aulum en 1765, recrudeció el debate parlamentario respecto del legítimo titular de la soberanía política sobre "un imperio tan grande" (ibíd., cap. VII). En medio de una "vehemente oposición" de la Compañía y de sus aliados en el Parlamento, contra la interferencia oficial en sus asuntos, como una "violación de los derechos de propiedad", un acuerdo temporal se plasmó en un acta de 1766, concediendo durante los siguientes dos años los ingresos territoriales en la India a la CIIO, a cambio de que ésta pagara al tesoro público 
400.000 libras anuales (ibíd.), y en 1769 fue extendido por otros cinco años (lib. IV, cap. IX).

Por vez primera, también se designó una comisión oficial de supervisores con poderes sobre la Dirección de la Compañía en la India, pero "el navío que los transportaba nunca alcanzó su puerto; ni jamás se recibió información alguna sobre ellos" (ibíd.).

Mill sintetizó la situación así: "más que verlo con claridad, quizá se sentía que las reglas de la propiedad individual no eran aplicables, sin fuertes restricciones, a una entidad artificial cuyas actuaciones tenían un alcance tan grande como para afectar profundamente los intereses de la nación en su conjunto" (ibíd.). En consecuencia, en 1772 el primer ministro y el Parlamento introdujeron "cambios radicales", entre ellos: a) invistieron el gobierno de Bengala, Bahar y Orissa en un gobernador general con un consejo de cuatro miembros; b) para el primer período de cinco años todos serían elegidos, entre los principales accionistas, por el Parlamento; c) posteriormente, por los directores de la Compañía, pero siempre sujetos a la aprobación de la Corona; d) fijaron los salarios respectivos en 25.000 y 8.000 libras anuales; e) subordinaron a tal gobierno las otras presidencias (Madrás y Bombay); f) dispusieron que toda la correspondencia de la India sobre asuntos civiles, militares y presupuestales pasaría por las manos del ministro; g) establecieron en Calcuta una corte suprema de justicia, con cuatro miembros designados por la Corona, sustrayendo este poder de la Compañía; h) decidieron que todas las adquisiciones realizadas mediante el uso de fuerzas militares o de tratados con gobernantes extranjeros pertenecerían al Estado y sería ilegal apropiarlas para el lucro personal de los funcionarios (ibíd.).

Pronto, sin embargo, las deficiencias serían evidentes. El gobernador así designado, Warren Hastings, terminaría procesado penalmente por el Parlamento mismo; pero este caso era apenas el paradigma de la burocracia en la India. La confusión jerárquica llegó a tal punto que los oficiales de las fuerzas armadas de la Corona "sentaron la doctrina de que no estaban obligados a obedecer a la Compañía" y la comisión legislativa se vio forzada a declarar que "cuando el rey presta sus tropas al servicio de la Compañía, y cuando pasan de ser pagadas por el rey a ser pagadas por la Compañía, su obediencia ante ésta era una condición necesaria y sobreentendida" (lib. V, cap. V). En consecuencia, "El general Stuart se abstuvo de (mantener) cualquier resistencia directa o declarada y, en cambio, eligió desvirtuar las directrices de la Presidencia y el Consejo (de la Compañía) poniéndoles obstáculos en su camino" (ibíd.). Para completar, la Compañía 
se declaró insolvente para el pago de las 400.000 libras anuales y de los dividendos, solicitando licencia para recurrir al "original método", según sarcasmo de Mill, de endeudarse con el público para pagarle las deudas. Además, en 1780 vencía el plazo para decidir sobre la renovación de la patente de privilegios.

Se reveló, entonces, un consenso político sobre una mayor regulación oficial; con un enfrentamiento, en cambio, respecto de si la Junta Directiva de la Compañía sería designada por el Parlamento o si una Junta Suprema de control sería designada por el rey (escogiendo seis miembros de su Consejo, entre ellos el Canciller y uno de los Secretarios de Estado). La primera alternativa tuvo un éxito fugaz pero, incluyendo el reemplazo del primer ministro (Fox), se impuso la última, recogida en la Reforma Pitt de 1784.

Entre otras cosas, observó Mill: "E1 nuevo ministro [Pitt] había sido ayudado para el triunfo sobre sus oponentes por todos los poderes de la Compañía [...] El ministro debía una gratificación [...] $y$, entre una serie de resoluciones que propuso [...] fue aprobada una disminución de los aranceles sobre el té, del 50\% al 12,5\% [...] Una parte de la ganancia monopolística (socavada por el contrabando) no constituía un sacrificio placentero para la Compañía. A ésta le pareció que los ingresos públicos constituían una fuente más adecuada para dicho sacrificio" (lib. V, cap. IX).

E1 presidente de la junta era "esencialmente un Secretario de Estado para la India [...] y, como rara vez asistían o eran citados los demás miembros, tomaba de hecho la totalidad de las decisiones sobre el gobierno civil y militar ejercido por la Compañía, excluyendo sólo sus transacciones comerciales" (ibíd.). Además, las apelaciones debían dirigirse al Consejo real, es decir, "a las mismas personas contra quienes se apelaba”.

Una prueba ácida de los alcances de las nuevas regulaciones surgió en 1787 cuando, gracias a otro de los alternados acuerdos de paz con Francia, la Compañía rescindió una solicitud por cuatro regimientos, pero la Junta de Control mantuvo la orden de su envío, con cargo a los ingresos territoriales de la Compañía en la India. A pesar de un acta de 1781, "eximiéndola del pago de tropas enviadas sin su solicitud", Pitt argumentó que "respecto de los asuntos militares y políticos, así como del recaudo, administración y aplicación de los ingresos por posesiones territoriales, no existe ahora decisión alguna que quede por fuera de los derechos de la Junta". El presidente de esta, Mr. Dundas, precisó: "El acta de 1784 implica que, si lo encontrase conveniente, la Junta de Control podría aplicar la totalidad de los ingresos de la India 
para su defensa, sin dejarle siquiera una sola rupia a la Compañía” (citados en ibíd., lib. VI, cap. I).

Confirmando esta interpretación, el Parlamento aprobó un acta "aclaratoria"; aunque, "para mitigar la alarma", las tropas ordenadas por la Junta en exceso de ciertos límites no serían de financiamiento obligatorio para la Compañía; así como el concurso de esta y del Parlamento sería requerido para los aumentos de salarios.

Entre los impactos sobre el sistema político, Mill destacó tres (ibíd.), que fueron generalizados en análisis posteriores. En primer lugar, financiada por fuera de la tributación (británica), “quedaría creada una fuerza militar más independiente del Parlamento que cualquier otra hasta ahora permitida por la ley" (según "la denominada Doctrina de la Constitución”, el rey sólo debía tener tropas sufragadas por el presupuesto aprobado anualmente por el Parlamento). En segundo lugar, se legitimaban "secretos que invocando los intereses nacionales deben permanecer ocultos". Institucionalmente, los comisionados en la Junta de Control "poseen en la Compañía el sospechoso instrumento de un Comité Secreto, ligado a ellos mediante un juramento [...] el cual puede ser impuesto a otros funcionarios, diseñándolo según las circunstancias". En tercer lugar, "mediante tal escalamiento militar [...] la Corona aumenta su clientelismo sobre los miembros de la Cámara de los Comunes, uniéndolos en una confederación tácita para sus propios beneficios" (añadió Mill: “contra todo mejoramiento político", con la indignación suscitada por "la atrocidad" de sobornar al controlador, un problema prioritario en su ensayo de 1820 sobre gobierno y desde los ensayos de Bentham en 1790; y por "la criminalidad" de "un gasto innecesario", pues "las tropas enrolables por la Compañía en la India podían ser mucho más baratas" que las del rey).

Al respecto, parece significativo que "Mr. Dundas [uno de los líderes parlamentarios] aventuró la curiosa proposición, respaldada por su experiencia, de que la circunstancia de quién era el [primer] ministro indicaba la tienda, como él la llamaba, donde el clientelismo en la India era distribuido al detal" (lib. VI, cap. I). Como ilustración, "El año en que Mr. Fox había sido ministro fue acusado de sobrecargar de clientelismo la India".

Los alcances, sin embargo, eran mayores. En un discurso, explicó Mr. Dundas que "la India rebosaba con el clientelismo [...] de los directores" (de la Compañía) y, como ejemplo, que "en un año habían enviado no menos de treinta y seis writers (principiantes sin experiencia, con altas expectativas de progreso, cuyo paradigma había sido Robert Clive en persona) a cargar el servicio civil”. Así mismo, 
el accionista y gobernador Hastings en la India fue acusado ante el Parlamento por "gastos extravagantes con el propósito de crear cargos y enriquecer a sus favoritos" (ibíd.).

A propósito, entre 1772 y 1784, Hastings aumentó las deudas de la Compañía de 13 a 26 millones de libras (lib. V, cap. VIII). De manera conexa, "eran de fama general el celo y los sentimientos del rey hacia Mr. Hastings” (lib. VI, cap. I, nota 27), lo cual contribuyó a su exoneración por la Cámara de los Lores de los trece cargos criminales que le fueron formulados por la Cámara de los Comunes.

Y la espiral tendía a autoperpetuarse, pues, hacia 1774, "La principal acusación contra la Junta de Propietarios era la de haberse llenado con funcionarios de la Compañía misma, que volvían [de la India] a Europa cargados con riquezas mal habidas. Ante esto [la disminución del número de accionistas con derecho a votar, requiriendo un mínimo accionario de mil libras esterlinas en vez de quinientas] [...] se convertía en una barrera contra la denuncia y el castigo, facilitando en vez de remediar los abusos" (lib. IV, cap. IX). Como anécdota, en 1765 , antes de arribar a Bengala por segunda vez, concentrado en la inminente conquista territorial pues, según sus propias palabras, "Debemos convertirnos en nababs nosotros mismos", Clive envió desde Madrás un poder a Londres, con las siguientes instrucciones: "Todo el dinero de mi propiedad, en fondos públicos, o en cualquier otra parte, $y$ todo el que pueda pedirse prestado en mi nombre, debe ser invertido en acciones de la Compañía, sin demorar siquiera un minuto" (lib. IV, cap. V).

Sin embargo, el puesto principal parecía destinado para la irrigación social del clientelismo: "Tan pronto como la administración de los asuntos de la Compañía de las Indias Orientales se convirtió en una fuente de clientelismo y poder, necesariamente ocurrió que las acciones eran tenidas para promover intereses con mucho más valor que el dividendo [...] principalmente por: 1) quienes aspiraban a un puesto en la Dirección [...] 2) el gran grupo de competidores por favores, por empleos y por contratos de suministros, los cuales incumbían a una considerable proporción de los propietarios de buques y comerciantes de Londres [...] 3) quienes aspiraban a contratos con el Almirantazgo, la Tesorería Nacional y otras entidades conexas, así como a empleos públicos, sabiendo que una base de influencia con el ministro del ramo era tener votos a su disposición en la Junta de Propietarios de la Compañía" (lib. IV, cap. IX).

Destacó Mill, entonces, que por fuera de los dividendos de las inversiones en el extranjero una fuente quizá más importante de renta 
era la "masa de riqueza equivalente a todos los cargos lucrativos en la India” (lib. VI, cap. VII). Cien años después, comenzando el siglo XX, se concluía en "The historians' history of the world": "Pocos aspectos de la administración en la India son más desagradables a primera vista que el hecho de que, con pocas excepciones, todos los cargos de mayor nivel, a los cuales corresponden los mayores salarios, estén confinados a los europeos" (The Encyclopaedia Britannica, 1904).

Y, en perspectiva, las implicaciones serían estratégicas, al menos en tres dimensiones. Primera: la difusión nacional de esa "masa de riqueza" y de las expectativas conexas en las potencias con probabilidad de controlar la cuarta parte de la población mundial, como logró hacerlo Inglaterra en el cenit de su imperio, antes de la primera guerra mundial. Segunda: sus impactos sobre el sistema político interno, estimulando "una confederación tácita" entre fuerzas previamente enfrentadas y un debilitamiento de los controles públicos sobre las decisiones del poder ejecutivo. Tercera: la creciente importancia de la "masa de riqueza equivalente a todos los cargos lucrativos" derivados de los privilegios del poder internacional, en general, como sugiere el análisis de Mill, más allá de su ilustración circunstancial con el caso de la India.

\section{ELEMENTOS DE DOMINACIÓN}

Además de la fuerza cruda, los siguientes elementos se destacaron en el proceso de dominación:

Simulación. En 1747, más de medio siglo después de estar aplicando la directriz secreta de la Compañía para "mantener la fuerza que nos convertirá en una nación en la India”, y diez años antes de que los británicos se apoderaran de Bengala, sobre la cual llegarían a dominar el subcontinente, el comodoro Griffin envió una carta invocando "la insolencia y la perfidia de los franceses" en contraste con "la más estricta amistad imaginable" de los ingleses. La respuesta del emperador mogol podría ser instructiva: "Durante largo tiempo los ingleses han sido muy obedientes y serviciales con nosotros; además de lo cual siempre han demostrado ser gente sincera; resultando muy doloroso que sufran estos problemas, desgracias y destrucción. Por lo tanto, ordeno [al nabab Anwar ad dien Khan] protegerlos, ayudarlos $\mathrm{y}$ asistirlos en todo; utilizar todos los recursos para castigar y expulsar a los franceses, para recuperarles a los ingleses su puerto marítimo (Madrás), sus derechos de establecerse como antes y de adelantar sus negocios para el florecimiento del lugar" (Nizam al Mulk, citado en ibíd.. lib. IV, cap. II). 
Soborno. Sir Thomas Roe advirtió a la Compañía en 1614: "un embajador les costará el doble [...] que un nativo influyente [...] incluyendo todos los sobornos necesarios" (citado en lib. I, cap. II). Y, en 1826, Mill concluyó: "Los sobornos privados para frustrar fines públicos fueron aplicados con alguna perseverancia en la política oriental; una maquinaria rara vez sin eficacia" (lib. IV, cap. V). Como ejemplo, cuando el emperador Feroksere manifestó por fin, en 1716, su aprobación para que la Compañía comprara los derechos sobre treinta y siete municipios (entre otros privilegios), los documentos fueron expedidos con el sello de un visir en vez del sello real, lo cual los dejaba sin eficacia ante las autoridades provinciales. El soborno de un favorito entre los eunucos del harem, con influencia ante el visir, venció la resistencia para la modificación.

En otro giro estratégico, ante la oferta de convertirse en el primer nabab bajo "protección" de los británicos, Meer Jaffier, el principal general del ejército de Bengala, desertó con sus tropas cuando comenzó la batalla de Plassy (1757), las volteó contra sus compatriotas y “con el costo de veinte europeos entre muertos y heridos, determinó la suerte de un gran reino y de treinta millones de personas" (lib. IV, cap. III), así como el futuro de la India.

(En la batalla del Río Jumna, en 1802, sin ser definitiva, "aunque pequeña en escala [...] las pérdidas indias fueron estimadas en tres mil hombres; las de los ingleses, en muertos, heridos y desaparecidos, fueron cuatrocientas ochenta y cinco" (Mill, lib. VI, cap. XII).

Fraude. Aparte de las compensaciones por pérdidas en la guerra de 1757, los miembros del Comité local de la Compañía reservaron, del tesoro del gobierno de Bengala a deponer, cinco millones de rupias como donación para las tropas británicas y otra parte para sí mismos: "280.000 rupias para el gobernador Drake, 280.000 para el coronel Clive, 240.000 para Mr. Watts y 240.000 para el Mayor Kilpatrick". Sin embargo, Ormichund, el influyente comerciante de Calcuta con el papel clave de convencer a Meer Jaffier, así como al nabab para que, contra la presión de sus ministros, dejara el mando del ejército a dicho general, "demandó cinco por ciento del dinero y una cuarta parte de las joyas del tesoro del nabab", lo cual les pareció a los miembros del Comité "una pesada ofensa [...] puesto que ansiaban todavía más para sí mismos”. Decidieron, por lo tanto, despojarlo aun de su respectiva indemnización, para lo cual, "Clive, a quien engañar le costaba muy poco cuando convenía a sus propósitos, propuso que dos tratados con Meer Jaffier fuesen escritos y firmados. En el primero, para mostrar a Ormichund, se reconocía su recompensa; lo cual sería por completo 
ignorado en el otro contrato, que sería el efectivamente ejecutado. En honor a la verdad, el almirante Watson se rehusó formar parte de este fraude; y dado que quedaba faltando su firma, el Comité la falsificó" (lib. IV, cap. III, nota 36).

Tecnología. En 1746, las tropas francesas al mando de Dupleix, gobernador de Pondicherry, "con la velocidad de su artillería dejaron perplejo más allá de toda medida a un ejército indio; ganaron sobre este una decisiva victoria con una ínfima proporción de fuerza numérica; y rompieron por primera vez el prejuicio que mantenía a los europeos bajo la sujeción de los poderes nativos"(lib. IV, cap. III). Cuatro años antes Benjamin Robins, un científico inglés, había publicado sus New principles of gunnery, paradigmas de una revolución europea en peso, costo, agilidad y precisión sobre blancos móviles, los cuales serían decisivos para la India, para Federico de Prusia (1756), para otras reformas de Jean Bauptiste Gribeauval en la artillería francesa (1765) y, luego, para Napoleón.

Cultura. En su History of warfare, Keegan concluye que la capacidad de perforación de las tropas europeas encontró una masa blanda en los ejércitos de los mogoles pues, prisioneros de su cultura esteparia, creían que "un ejército de caballería puede ser exitoso sin un núcleo de infantería", parafraseando al fundador de la dinastía (Babur, 1526). Mediante la contratación de oficiales europeos, franceses en particular, procuraron un viraje durante el siglo XVIII, pero esa cultura constituía un pesado fardo. Un ejemplo notable fue "Meer Causim [quien] había sido muy ambicioso sobre la introducción del orden europeo entre sus tropas [...] [En Geriah, en 1762, contó con] un cuerpo de tropas [...] mejor disciplinadas que las llevadas alguna vez al campo de batalla por cualquier otro comandante nativo [...] entre ellas cipayos, o sea soldados disciplinados al modo europeo, bajo el mando del alemán Sumroo [...] Fue el combate más severo enfrentado hasta entonces por los ingleses contra un ejército indio [...] Este rompió una parte de la línea inglesa, les arrebató dos cañones y atacó al regimiento 84 por el frente y por la retaguardia [...] Sin embargo, la disciplina de los ingleses agotó la impetuosidad de sus atacantes, lo cual les reportó a aquellos una completa y brillante victoria" (Mill, lib. IV, cap. V).

Otras secuelas culturales fueron: la negligencia naval en relación con el poderío terrestre; las fracturas de mando, pues "en los ejércitos indios cada general responde por la manutención de sus propias tropas" (lib. IV, cap. III), con pérdidas de especialización y eficiencia militares si se dedicaba a sus cultivos, o un colapso de recursos si se concentraba sólo en las tareas militares; la personificación en vez de la 
complejidad organizacional, ya que "La muerte de su líder es la señal para la desbandada de un ejército indio" (lib. IV, cap. V), y Mill indicó al menos dos derrotas sólo porque durante las batallas los príncipes se apearon de su elefante; la sacralización del transporte y el comercio de cereales en la casta de los "brinjarries", respetados por todas las partes, inclusive en casos de guerra, lo cual permitió a los ejércitos británicos penetrar hasta las regiones más lejanas. "Lo más terrorífico en una marcha masiva hacia Seringapatam [...] era la hambruna [...] [Pero] los brinjarries tenían cincuenta mil bueyes transportando cereales para el ejército [británico], aun desde los campos del enemigo mismo, en cantidades que ningún esfuerzo oficial podría haber igualado" (lib. VI, cap. IV). Además, la costumbre de "los nativos [quienes] siempre cierran sus operaciones [militares] antes del anochecer" (lib. IV, cap. III) ofreció ventajas para Clive en Arcot, durante la conquista de Bengala; y casi cuarenta años después seguía aprovechándose para la dominación sobre Mysore: "un destacamento [...] se aproximó al campo del enemigo antes de medianoche, penetró sin ser descubierto, mató a bayoneta cerca de cien tropas y otros tantos caballos antes de que se diera la alarma general; después disparó varias cargas para mantener la consternación, sin perder siquiera un solo hombre" (lib. VI, cap. IV).

Contratación difusa. La maestría para explotar a la parte más débil vinculada mediante un contrato difícilmente encontraría mejores ilustraciones que las del gobernador británico en la India entre 1772 y 1786 , hasta el punto de haber explicitado el principio con todo rigor: "Como ningún período fue estipulado sobre la continuidad de la brigada temporal, o de las tropas de reemplazo en servicio [del nabab de Oude], así como ningún modo fue prescrito para retirarlas; tales plazo y forma deben ser indicados por la necesidad y el interés común de ambas partes. Esto debe ser determinado ya sea por él o ya sea por nosotros. Si un acuerdo resulta inalcanzable, ante tales alternativas, 1a parte más poderosa debe decidir" (Warren Hastings, carta citada en lib. V, cap. VIII, nota 10). Todo se refería, en el dominó de una región tras otra, a un ejército que entra como aliado y defensor, para después mantener la ocupación. Según palabras de Mr. Francis en un Consejo de la Compañía, "el ejército inglés ha devorado sus rentas y su país [ Oude] bajo la bandera de defenderlo".

Por su parte, Mill elevó tal principio político como una ley general en la teoría de los contratos: "En todos los acuerdos entre partes, cuando una es en un grado considerable más fuerte que la otra, todas las ambigüedades en los términos son tarde o temprano forzadas a 
la interpretación más favorable para la parte más poderosa, y menos favorable para la parte más débil" (lib. VI, cap. I). Aplicándola a alguna negociación concreta, explicó: "El nabab [...] era la parte más débil y, como tal, tenía el máximo interés para la protección de regulaciones bien definidas" (lib. IV, cap. IV).

Extorsiones. Para muestra del esquema: en 1770 la Compañía reconoció al rajá de Benarés y a su línea sucesoria, "en los mismos términos [que a su padre], excepto un pequeño aumento en el pago anual [...] Y se acordó que 'ningún incremento del tributo sería demandado en adelante'. [En 1774 se confirmó dicha cláusula] sin otra condición que el pago de un tributo fijo e invariable [...] [y se estipuló que] en tanto cumpliera sus compromisos, 'ninguna otra demanda, de clase alguna, le sería formulada por la Honorable Compañía' [...] En estos términos el arreglo fue concluido; y el rajá continuó pagando su tributo (de trescientas mil libras anuales) con una exactitud rara vez ejemplificada en la historia de los príncipes tributarios del Indostán" (lib. V, cap. VII).

Sin embargo, en 1778 se le requirió contribuir con el sostenimiento de más tropas y caballería, "un mero aumento de su tributo con distinto nombre” según uno de los directivos que transitoriamente se opuso. "Cuando el rajá accedió [después de rebajarle algo la nueva carga], declaró expresamente que era sólo por un año [y solicitó un plazo. Pero el gobernador propuso] exigirle la totalidad inmediatamente [...] El rajá argumentó pobreza; y rogando indulgencia, se comprometió al pago en seis o siete meses [...] [Pero] el gobernador trató esta simple solicitud como una gran ofensa [...] y se ordenó exigirle el pago en cinco días [...] declarando que el incumplimiento sería tratado como una negativa absoluta [...] El siguiente año la demanda fue renovada [...] El rajá insistió en la estrechez de sus circunstancias; en las dificultades impuestas por una carga tan pesada; en la exención garantizada por los términos del tratado sobre cualquier aumento en su tributo [...] y en su estipulación expresa de que la excepción anterior era sólo por un año [...] El gobernador respondió en términos más imperiosos y duros que antes, amenazándolo con una ejecutoria militar, a menos que el pago fuese inmediato e incondicional. E1 rajá insistió en su solicitud, aun en los términos más sumisos y suplicantes. Se ordenó a las tropas marchar y fue obligado a pagar 2000 libras como multa por la demora, bajo el concepto de gastos militares para su propia coacción, además de la demanda original. En 1780 la exacción fue renovada [...] [E1 rajá mandó ofrecer al gobernador] un regalo secreto (por unas veinte mil libras) el cual fue finalmente aceptado [...] La contribución, sin 
embargo, le fue extraída [...] [Y] los intentos del rajá para obtener un pequeño plazo fueron tratados como delincuencia renovada; debido a lo cual el gobernador le impuso una multa de 10.000 libras y ordenó a las tropas marchar. De nuevo, el rajá se sometió y el dinero fue cancelado [...] Pero [...] ahora, otra carga adicional le fue impuesta [...] $\mathrm{E} 1$ gobernador quería dinero y había resuelto obtenerlo del saqueo del infeliz rajá [...] [quien] procuró moderar la furia de la tormenta enviando al gobernador una oferta para el servicio público [de unas doscientas mil libras, transmitiendo las exacciones crecientes, claro está, a sus propios súbditos]; lo cual fue ridiculizado. Una suma [de unas quinientas mil libras como mínimo] le fue demandada perentoriamente [...] Ante la aproximación del gobernador a las fronteras de los dominios del rajá, este le solicitó una entrevista donde le 'profesó [...] contrición [...] devoción [...] y colocó su turbante en mi canto', pero fue despedido sin concederle valor a sus declaraciones [...] [Ya] en Benarés recibió un memorando de reclamos y demandas [...] El rajá respondió en otro [...] con explicaciones [...] mostrando que no merecía trato tan severo. El gobernador, sin más comunicaciones, lo puso bajo arresto" (lib. V, cap. VII). Para reemplazarlo, un joven de diecinueve años de edad, sospechoso de incapacidad mental, fue escogido por los británicos, con un compromiso para otro aumento de los tributos.

El rajá logró huir pero su familia quedó en el Fuerte de Bidgegur, sitiado por el ejército británico. La madre del rajá "logró, antes de abrir las puertas del fuerte, que era su propia residencia, acordar algunas ventajas sobre su seguridad, sus bienes personales y otros efectos [...] Cuando la princesa, con sus familiares y cortejo, en número de trescientas mujeres, además de los niños, salieron del castillo, la capitulación fue vergonzosamente violada; sus efectos personales fueron saqueados; y sus personas ruda y deshonrosamente tratadas [...] En sus cartas al comandante, el gobernador Hastings usó expresiones que implicaban que el saqueo de aquellas mujeres era la debida recompensa de los soldados" (lib. V, cap. VII). Mill aclara que en un acto de "honor y gallardía” el comandante se negó a participar personalmente en tal pillaje, aunque debió autorizarlo.

Máscaras. En carta al Comité Selecto, el 16 de enero de 1767, Clive señaló: "A partir del contrato para nuestra adquisición de rentas territoriales [en Bengala], el poder que pertenecía al Subah de estas provincias está, de hecho, totalmente investido en la Compañía. Nada le queda a él, sino el nombre y una sombra de autoridad. Es indispensable, sin embargo, aparentar que veneramos este nombre, 
esta sombra [...] [Así] cualquier otra intervención foránea puede ser aplastada sin evidente interposición de nuestra propia autoridad [...] cualquier acto directo del poder inglés, cuando podría ser ejecutado por el nabab en nuestro lugar, sería despojarse de la máscara" (lib. IV, cap. VII, nota 15). Casi tres años después, el gobernador Verelst reconocía: "Una autoridad tan complicada y dividida genera intrigas y opresiones desconocidas en cualquier otro período [...] Pero de manera insistente y perentoria teníamos prohibido reconocer cualquier autoridad nuestra sobre los funcionarios del gobierno" (lib. IV, cap. VII, nota 16).

En el caso del nabab de Oude, Asoph ul Dowla at Chunar, quien fue sometido en 1781 a un proceso de extorsión calcado del rajá de Benarés, "Los deseos del gobernador [Hastings] estaban fijados; un desempeño absoluto era exigido del Residente [británico], sin otra limitación al propio ejercicio de su poder que lo recomendado por la prudencia y 'todas las demostraciones externas y ostensibles de respeto hacia el nabab' (según instrucciones literales del gobernador)” (lib. V, cap. VIII). La persistencia de este último elemento es destacable. Por ejemplo, en 1802, precisamente cuando el nabab era objeto de las mayores humillaciones, sometido a ceder la soberanía sobre su territorio, otro gobernador [Wellesley] le fingía en público "un estudiado despliegue de respeto personal" (lib. VI, cap. IX).

La estrategia dependía, claro está, de conveniencias circunstanciales. Desde 1765 Clive había indicado: "Debemos convertirnos en nababs nosotros mismos, de hecho, aunque sin tal título; o quizá completamente, sin disfraz alguno" [carta a Mr. Rous, citada en lib. IV, cap. V]. Diez años más tarde (1775) el gobernador Hastings escribía: "Es tan visible como la luz del sol que cada orden se origina en nuestro propio gobierno [...] que el nabab [de Bengala] es apenas parte de una comparsa [...] que carece [aun ahora] de la sombra de autoridad, y hasta sus más inmediatos subalternos reciben su nominación explícita desde las dependencias de la Compañía” (lib. V, cap. II). En 1799, el gobernador Mornington anunció: “Considerando los inconvenientes y apuros surgidos para todas las partes, bajo el doble gobierno y los conflictos de autoridad establecidos desafortunadamente en Oude, Carnatic y Tanjore, he resuelto reservar para la Compañía los poderes más amplios posibles e indisputables" (lib. VI, cap. VIII). En $1802 \mathrm{el}$ nabab de Oude fue retirado y pensionado por la Compañía como uno más entre sus funcionarios. Y, sobre el futuro, el título de un capítulo siguiente de Mill es significativo: "E1 nabab de Surat depuesto. E1 rajá de Tangore depuesto. El nabab de Arcot depuesto”. 
Ventaja institucional. Gracias a la cura de una enfermedad íntima que difería su próximo matrimonio, el emperador Feroksere le permitió elegir una recompensa al médico Hamilton (miembro de una embajada), quien solicitó para la Compañía, su empleadora, "los siguientes beneficios: 'protección para los cargamentos ingleses [...] eliminación de todos los aranceles a cambio de una suma fija, reposición de tres villas contiguas a Madrás, en perpetuidad [...] arrendamiento de la Isla de Diu [...] traspaso a jurisdicción de la Compañía de los procesos contra deudores en Bengala [...] eliminación de inspecciones aduaneras para los cargamentos de la Compañía [...] licencia para comprar los derechos sobre los territorios de treinta y siete municipios [...] en la misma forma como había ocurrido con Calcuta, Suttanutty y Govindpore". Dada la oposición de altos funcionarios, insistentes solicitudes fueron elevadas al emperador, quien al fin, en abril de 1716, "emitió mandatos confirmando todos los privilegios de la petición" (lib. IV, cap. I).

En general, Mill observó: "La historia oriental ejemplifica con frecuencia cómo los más grandes eventos dependen de las más pequeñas causas" (lib. IV, cap. III), lo cual parece apuntar hacia las debilidades del caudillismo y del "despotismo oriental" ante la complejidad democrática.

Convencionalmente, el fraccionamiento del poder entre príncipes enfrentados, que nunca alcanzaron siquiera, indica Mill, un grado de organización como el de los príncipes electores alemanes, se considera la clave de la dominación sobre la India prebritánica; aunque el despotismo se sitúa en el extremo opuesto del fraccionamiento. Una salida lógica encontraría, por supuesto, que el poder absoluto fluctuaba, según la correlación de fuerzas, entre un polo real y otro apenas nominal, como de hecho comprobaron los ingleses con su dominó de alianzas y confrontaciones pero, sobre todo, cuando en la toma de Delhi tuvieron entre sus propias manos al emperador, en ese momento apenas una figura que les inspiraba compasión.

En el otro polo, y en otras circunstancias, sin las concesiones personales del emperador a los ingleses, en momentos críticos, aun en contra de sus propios ministros, la inversión y los costos de la conquista hubiesen sido distintos; sin la cabeza visible del emperador como único símbolo del mando supremo, algunas batallas hubiesen sido distintas. Si los tratados hubieran pasado por algún Parlamento indio, los costos y beneficios de los avances británicos, incluyendo los sobornos, hubiesen sido distintos. 


\section{LA EVALUACIÓN FINANCIERA DE LA GUERRA}

En 1780, Mr. Francis, uno de los más notables directores en la India, regresó herido a Inglaterra, después de un duelo con el gobernador Hastings, quien tras un largo enfrentamiento lo acusó de violar su compromiso para una ampliación de la guerra contra los maharattas. $\mathrm{Y}$ en Londres, sin escenificar tal crudeza, la lucha partidista sobre la guerra en la India también era candente.

Por una parte, las expansiones militares en el exterior fortalecían las posiciones de la aristocracia más conservadora; además de beneficios directos, le suministraban un fondo clientelista en expansión para apalancar su influencia sobre partidarios, neutrales o adversarios; y por añadidura debilitaban el control del Parlamento.

Por ejemplo, en 1797, Lord Mornington, quien utilizaría la menor excusa para ampliar la guerra de conquista hasta sus confines, fue "sorpresivamente" designado gobernador en la India, después de un anuncio oficial sobre el nombramiento de Lord Cornwallis y de incumplir una promesa a Lord Hobbart. Aclara Mill que "un brillante discurso antijacobino pronunciado en la Cámara de los Lores” fue la recomendación que decidió al primer ministro a preferirlo en el cargo; y que Mornington arribó a Calcuta en 1798, “inflamado más de lo usual [...] con las pasiones ministeriales de pavor y odio que ardían en Inglaterra ante el poder [revolucionario] francés" (lib. VI, cap. VIII). Posiciones análogas observó en gobernaciones anteriores, en particular la de Hastings, por lo cual concluyó: "Los enemigos de las reformas en la India y los enemigos de las reformas en Inglaterra son todos de la misma casta" (lib. VI, cap. VII, nota 28).

Por otra parte, de tiempo atrás el Parlamento había prohibido la expansión territorial en la India; la entrada hostil a cualquier territorio ajeno, excepto en caso de legítima defensa; las alianzas con otras potencias para dividirse territorios adquiribles, y los préstamos de tropas a los príncipes nativos. Además, en 1783 renovó de manera explícita tales prohibiciones y legisló sobre procedimientos para su eficaz cumplimiento [lib. V, cap. IX]. A parte de efectos indirectos, una de las razones más notables era, claro está, la presión sobre la contribución pública para el financiamiento de la guerra. "De acuerdo con la doctrina que guió a la legislatura para tal resolución, toda extensión del territorio [en la India] era mala porque su defensa costaba más de lo que se podía forzarlo a producir" (lib. VI, cap. VIII).

Y a pesar de que "un fundamento decidido en la política de la Compañía era no retener bajo su administración las provincias (como Corah y Allahabad) [...] cuyo gasto de gobernarlas [...] excediera el 
máximo ingreso que podrían rendir" (lib. V, cap. I), en 1769 el precio de las acciones de la Compañía cayó el 60\% como consecuencia de "los desastres de la guerra en Carnatic y su desorden sobre el gobierno de Bengala" (lib. IV, cap. VIII); en 1773, el Comité de directores exigió una reducción de los gastos militares, pues los ingresos corrientes del gobierno de Bengala no alcanzaban para sus gastos corrientes (lib. V, cap. I); en 1779, "como siempre, las finanzas de la Compañía eran angustiosas y afectadas intensamente por la guerra" (lib. V, cap. VIII), y en 1780, "las finanzas de la Compañía eran una fuente de angustia en todas las regiones de la India [...] reduciéndose al expediente de contraer deudas" (lib. V, cap. VI). En un juicio sumario con la evaluación de proyectos, entre 1772 y 1786 , "La administración de Mr. Hastings (notable por su agresividad en la expansión territorial) incrementó la deuda de la Compañía en cerca de doce y medio millones de libras; $\mathrm{y}$ un interés del cinco por ciento sobre esta deuda adicional es mayor que los ingresos adicionales" (lib. V, cap. VIII).

Por consiguiente, en una aparente síntesis del sentimiento nacional, Mill concluyó: "En la India, la verdadera prueba del gobierno, en relación con los intereses de la nación inglesa, se encuentra en sus resultados financieros". Pero, como se ha visto, las tasas de retorno eran muy distintas para los individuos y grupos que mejoraban sus posiciones y se enriquecían mediante la expansión de la conquista. Por ejemplo, el ejército británico se habría salvado del fracaso y de las ingentes pérdidas en la primera marcha hacia Seringapatam, si hubiese aceptado que "para su país era mejor la paz que la guerra. Mejor para su país. Sí. Pero no mejor para ellos, porque perderían la adquisición de botín, promociones y gloria" (lib. VI, cap. IV, nota 7).

Para terminar el período analizado en la Historia de Mill, entre 1797 y 1805, "Lord Wellesley [Richard, Conde de Mornington, Marqués de Wellesley; hermano de Henry Wellesley, su secretario en Calcuta y representante plenipotenciario; y de Arthur Wellesley, general y gobernador de Seringapatam en 1803, comandante en Waterloo en 1815, Duque de Wellington] fue considerado como un gobernador muy costoso y ambicioso; la mayor parte de su administración había sido una escena de guerra y de conquista [...] Los directores mismos y el Ministerio empezaron a alarmarse ante la acumulación de la deuda india y las dificultades pecuniarias que acosaban a la Compañía" (lib. VI, cap. XIII). Aumentó el déficit anual de 119 mil a un cuarto de millón de libras, y las deudas de la Compañía en la India pasaron de 9 millones a 25 millones de libras. En estas condiciones, resultó reemplazado por Lord Cornwallis, quien recién posesionado, en julio 
de 1805, escribió: "He decidido finalizar mediante la negociación, si puede lograrse sin pérdida de honor, una guerra en la que aun el más brillante éxito ningún beneficio sólido nos aportaría; y en la que, si continuamos, resultaremos envueltos en dificultades financieras que difícilmente estaremos en capacidad de superar" (citado en ibíd.).

En general, Mill explicitó "el principio" subyacente: "Si el nuevo territorio aumenta los ingresos más que los gastos, resulta ventajoso; si aumenta los gastos tanto como los ingresos, resulta dañino [...] observando que los intereses y la amortización del dinero invertido para lograr la adquisición deben ser tomados en cuenta. Si ha sido mediante una guerra, por ejemplo, el gasto total de la guerra debe ser considerado" (ibíd.).

Tal lógica implicaba, por supuesto, volubilidades ante operaciones asociadas con beneficios esperados para los parlamentarios individuales, los grupos de interés con influencia en el legislativo o la población representada. Por ejemplo, el ataque de Wellesley contra el Sultán Tipoo, para la conquista de Seringapatam, disfrazando el objetivo con argumentos de seguridad, "fue el acto más cuestionable de su administración, aunque hasta ahora ha estado exento de censura”. Es más, “será imposible demostrar que tal guerra [...] era de legítima defensa, excepto argumentando que ninguna guerra con la consecuencia de aumentar la seguridad de la nación podría tener un objetivo distinto"(ibíd.). "Los males [de tal agresión] eran, en primer lugar, una violación de la resolución del Parlamento que prohibía la extensión del territorio [británico en la India]; pero que siempre había sido violada con tan poca ceremonia, y últimamente [1800] de una manera tan extraordinaria, que ello constituía un objeto de trivial importancia”. "Era propio del gobernador [Wellesley] tratar la resolución del Parlamento con desprecio, en la medida en que el Parlamento mismo pronto declararía que así lo merecía, agradeciéndole y aplaudiéndolo por la violación flagrante de esa resolución" (ibíd.). Y diez años antes, a pesar de que notables dirigentes denunciaron la agresión de Cornwallis sobre Mysore como "una confederación ilegal para el pillaje”, el Parlamento se unió a la Compañía, votando para esa operación un aumento de los regimientos y de la artillería del rey en la India. En síntesis, Mill advierte: "Que mediante las acciones de conquista la Compañía hubiese expandido sus territorios, en violación de los principios declarados y de las resoluciones del Parlamento, y que sin embargo haya sido aplaudida por el Parlamento y por la nación, fue tenido en cuenta por el mundo, y todavía no lo ha olvidado" (lib. VI, cap. IV).

El pragmatismo financiero era, pues, corriente y aplicado desde el comienzo. Verbigracia, "El gobernador [Hastings] parecía pensar 
que el éxito, con el dinero en mano, santificaría los medios. Sabía bien que esta regla se cumple con demasiada generalidad" (lib. V, cap. VIII, nota 36).Y en la retoma de Calcuta, en 1757, "Entre sus instrucciones, una de las más perentorias era regresar a Madrás con la totalidad de sus tropas", pues en medio de una guerra con Francia se esperaba un ataque en la costa. Pero, "Clive percibió oportunidades espléndidas y lucrativas en Bengala; ignoró todas las demás consideraciones; violó sus instrucciones y permaneció" (lib. IV, cap. III) para derrocar al nabab Suraja Dowla, mediante "una revolución cuya administración fue confiada al residente [británico] en la capital”, y cuya pieza central fue la traición de su principal general, Meer Jaffier, en Plassy. A pesar de que, precisa Mill, el tesoro encontrado estaba por debajo de las expectativas, dispusieron inmediatamente de 2.750.000 libras y otras sumas posteriores. Clive fue ascendido, más tarde investido con los privilegios de Lord y se hizo rico (según Strachey, cap. II, en el acto Clive recibió 234.000 libras, equivalentes a unas 2.300.000 libras de 1959, sin contar su posterior jaghire anual de unas 270.000 libras de 1959).

Sobre otros costos, caben algunas muestras. "En 1764 nos asociamos con él [el visir de Oude] para incendiar y vandalizar a su país”, reconoció Hastings como presidente del Consejo Directivo en Calcuta, y "de acuerdo con las instrucciones recibidas, destruimos más de mil villas. Si las lluvias no lo hubiesen impedido, hubiéramos hecho un daño mucho mayor [...] El ejército en pleno presenció escenas que no pueden ser descritas", declaró el coronel Champion.

A cambio de unas 500.000 libras (del momento), pagadas por el Visir de Oude, los gobernantes británicos de la India se comprometieron, en 1773, a exterminar la nación de los Rohillas. "He recibido la carta de Vuestra Excelencia mencionando que si los Rohillas se hacen culpables de romper su acuerdo [para el pago de cuarenta lacs de rupias, fraudulentamente exigidas], nosotros los exterminaremos por completo, y estableceremos a Vuestra Excelencia en el país, en cuyo caso pagará a la Compañía cincuenta lacs de rupias y la exonerará de tributos al rey" (Hastings en documento citado en lib. V, cap. I, nota 48). Como resultado, "Probablemente nunca fueron los derechos de conquista abusados con mayor salvajismo [...] Cada uno con el apelativo de Rohilla fue acuchillado o pudo salvarse sólo con la fuga y el exilio" (ibíd., nota 48).

Para terminar, en la primera marcha hacia Seringapatam, en 1790, el Sultán Tipoo mandó ofrecer una paz negociada, pero el gobernador y comandante Cornwallis tomó la decisión de rechazar al embajador sin escucharlo, ante lo cual “el júbilo invadió al ejército" británico. Con- 
cluyó Mill: "Es otra prueba, entre muchas, del hecho muy destacado de que masas enteras de hombres son capaces de desear la muerte de miles de sus semejantes, de un solo tajo, simplemente para su propio lucro" (lib. VI, cap. IV, nota 7).

\section{EL ANÁLISIS DEL COMERCIO COLONIAL}

\section{MONOPOLIO Y COMPETENCIA}

En La historia, el análisis del comercio aflora sobre la coyuntura de 1730 , cuando un reciente cambio de soberano, una oposición parlamentaria fortalecida y los debates en una prensa libre nutrieron los proyectos para abolir el monopolio de la Compañía. El más opcionado establecía la libertad comercial con la India para cualquier empresa británica; mientras reducía el monopolio de la sociedad anónima a la administración de los fuertes y las bodegas para "la preservación y el crecimiento" colectivos.

Mill dejó en duda si una infraestructura de tales características y dimensiones sería imprescindible. De otro lado, el potencial agremiativo de competidores dispersos, al compartir instalaciones y una inversión, podría considerarse útil contra el poder y la influencia de un monopolio establecido. Para empezar, los nuevos "peticionarios" debían reunir y reemplazar los 3,2 millones de libras avanzadas por la Compañía al gobierno, al 5\%, lo cual ofrecieron en condiciones más favorables.

Fue tajante Mill, en cambio, sobre la operación comercial, señalando que "Cualquier ganancia derivada del monopolio [...] se perdía mediante la dilación, la negligencia y el derroche de su administración [...] Esto no es producir sino su reversa [...] en vez de enriquecer a la nación lo impide" (lib. IV, cap. I). Añadió que sus dividendos no habían excedido el 8\%, un nivel superado por empresas británicas compitiendo entre sí en otras partes del mundo, y argumentó que si el comercio con la India resultaba en realidad beneficioso, la competencia le haría fluir tanto capital como requiriese, sin necesidad de la Compañía.

En síntesis: "El cambio del monopolio hacia la libertad en el comercio con África permitió obtener grandes beneficios nacionales [...] La competencia [...] aun con un capital idéntico, incrementa la masa de negocios [...] el producto anual [...] la riqueza y la prosperidad del país [...] La mayor economía, diligencia, inteligencia y habilidad del emprendimiento competitivo permiten al mismo tiempo precios menores y una ganancia sobre el capital no inferior a la del monopolio, de acuerdo con la experiencia” (ibíd.). 
Respecto de la breve competencia ruinosa entre dos compañías patentadas para la India, antes de su fusión en 1702, distinguió el enfrentamiento letal en un duopolio, con estrategias de dumping recíproco, de la libre competencia, con muchos participantes potenciales, ganancias normales y precios paramétricos, "principio que produce la harmonía y prosperidad del comercio en todos los casos donde la libertad prevalece".

Ningún avance sobre el análisis más sistemático de casi medio siglo antes en La riqueza de las naciones parece destacarse y, quizá por esto, Mill se sintió obligado a desarrollar sus planteamientos cuatro años después de la primera edición de su Historia, en sus Elements of political economy (1821, cap. 3, sec. XVIII, “Colonies”). Innovó con una aplicación implícita de las elasticidades de demanda, concluyendo que mientras menos sustitutos existan para las exportaciones del país colonialista (necessaries vs luxuries), mayor es su capacidad para poner en su favor los términos de intercambio a través de un monopolio (monopsonio) como la Compañía.

(Inquieta el anacronismo de que un manual de 1821 para principiantes, pues así lo proyectó y lo catalogó James Mill, corrija la incoherencia de monopolios factibles sólo con altas elasticidades de demanda, enseñada por los manuales de microeconomía aún en 2008).

Para casos como la propuesta de 1730, el único beneficio surgiría de cerrar el resto del mundo a las exportaciones de la colonia, para deprimir sus precios ante la metrópolis, mientras que resultaría torpe restringirle la libertad de importaciones. Pero tal planteamiento supone que la colonia produciría en condiciones distintas del capitalismo competitivo, pleno empleo en la metrópolis y eficiencia competitiva entre sus exportadores.

En todo caso, Mill pasó a aceptar que un monopolio comercial podría beneficiar al país colonialista, coincidiendo con Ricardo contra la tesis de Smith. Sin embargo, The principles presentaban desde 1817 una teorización más desarrollada sobre los términos de intercambio, las ventajas comparativas y el ajuste monetario. Esto constituiría, entonces, uno de los referentes de "Colony", un ensayo de 1825.

\section{DISTRIBUCIÓN Y EFICIENCIA}

En la nueva elaboración, debido a la reciprocidad de los precios, lo ganado por la metrópolis sería igual a lo perdido por la colonia, en el mejor caso imaginable: inexistencia de una mejor asignación para los recursos privilegiados con la limitación de la competencia. 
Bajo un supuesto implícito de pleno empleo, tal caso parece "cerca de lo imposible"; de donde Mill concluyó que el colonialismo resultaba ineficiente en términos del producto conjunto de las dos economías. $Y$ le sobrepuso una desutilidad social por la redistribución injustificada, "como si Yorkshire fuese oprimida y explotada para beneficio de Midlesex".

Apoyado en Ricardo, descalificó las conclusiones de Smith sobre: a) un aumento de la tasa de ganancia por el éxodo de capitales desde la metrópolis; b) un consecuente aumento de los precios, y c) una pérdida de competitividad como secuela. Respecto de c), aun si b) fuese correcta, opuso las ventajas comparativas a las absolutas, remitiendo al ajuste monetario ricardiano; b) fue el error más burdo de Smith, corregido por Ricardo; pero la crítica de a) sólo tenía como base una autorrefutada incoherencia de Ricardo (sobre la tasa de ganancia alterable únicamente por cambios en los salarios).

Al final, Mill reconoció beneficios comerciales para un país colonialista en dos casos: el monopolio de una compañía; y la apertura del mercado colonial a empresas de la metrópolis, competitivas entre sí pero incapaces de competir con el resto del mundo. En este último caso, los beneficios no provendrían de un mayor empleo (pues supuso permanente y plena utilización de los recursos); ni de una mayor tasa de ganancia para las empresas (pues su competencia las reduce al nivel normal, y rechazó el aumento de este nivel, argumentado por Smith); ni de economías de escala (pues no las consideró); ni de ahorro de los costos friccionales de las reasignaciones; sino de un mayor producto físico transferido por la colonia.

En el libre mercado mundial tendría un menor precio la producción $(Q)$ de las empresas ineficientes de la metrópolis; esta recibiría, entonces, gracias a la colonia, una mayor cantidad de bienes a cambio de $Q$. Sin embargo, bajo las condiciones propuestas, esa cantidad adicional de bienes tiene también un costo adicional para la metrópolis. De hecho, algunas veces Mill midió los beneficios y las pérdidas en cantidades de trabajo y otras veces en cantidades de bienes, sin advertir que, como había subrayado Ricardo, esto puede conducir a conclusiones inconsistentes.

\section{UTILITARISMO Y COLONIALISMO}

\section{INDICIOS SOBRE UN UTILITARISMO COLONIALISTA}

En los dos primeros volúmenes de la obra de Mill se considera el problema de "discernir el verdadero nivel de civilización de los hin- 
dúes [...] como un objetivo de la importancia más práctica para el pueblo de la Gran Bretaña, cargado con el gobierno de aquella gran porción de la humanidad" (lib. II, cap. x). En este proceso despliega una universal etnografía comparada, quizá una síntesis única en su tiempo, fuente de teorizaciones subsiguientes; y recurre a contrastes con los asirios, egipcios, persas, árabes, griegos, incas, mayas, tártaros, africanos, cherokees, romanos, chinos o normandos para refutar "la fantasía de los europeos que buscan objetos de admiración”, por su elevación y refinamiento, en la sociedad india. En concreto, "Ha sido desafortunado que una mente tan pura, tan cálida en la búsqueda de la verdad y tan entregada al conocimiento del Oriente, como la de Sir William Jones, haya adoptado la hipótesis de un alto grado de civilización en los principales países de Asia. Esto lo apoyó con las ventajas de su autoridad y de una reputación brillante; y ganó para este planteamiento tanto crédito que por un tiempo ha resultado muy difícil lograr alguna atención en su contra" (lib. II, cap. X).

Por lo demás, lo anterior refleja una línea divisoria entre intelectuales europeos de la época. En su apoyo, Mill cita repetidas veces a Voltaire, incluida su referencia a Rousseau como la persona "con el mayor apetito conocido por volver a caminar en cuatro patas".

Desde las matemáticas, pasando por la gramática, la ingeniería, la arquitectura, la literatura, la escultura, la historia, la geografía, el derecho, el gobierno, la agricultura, los impuestos, las obras públicas, el "arte militar", la beneficencia, la medicina, la familia, la propiedad y las costumbres, hasta la religión, su conclusión es la misma: los indios son inferiores a los europeos. Es más, llevó su perspectiva histórica hasta los orígenes para enfrentar el argumento de una degradación nativa como efecto de la conquista. De paso, aprobó y usó adjetivos calificando a una sociedad completa, al estilo de "afeminados", "inmorales", "deshonestos”, "mentirosos”, “vulgares”, “crueles”, “serviles” o "pérfidos", y a sus artes como "carentes de atracción, antinaturales, ofensivas y con frecuencia repugnantes". A los poemas del Mahabarata y el Ramayana los denominó "producciones grotescas".

Incluso siguió la tesis de que unas religiones eran más racionales que otras y llegó a estimular sospechas cuando, resbalando sobre su férrea lógica, el misterio de una trinidad divina le resulta absurdo en un caso mientras omite la mención en otros; y, de manera similar, cuando su puritanismo se enfrenta a referencias eróticas, literarias o visuales, seculares o religiosas, descalificándolas como grotescas y escandalosas. Sólo admite como excepciones la superioridad india en la belleza femenina, la capacidad para el estoicismo y la eficiencia de 
sus procesos judiciales; en contraste con los cuales, con descripciones y adjetivos similares, expone su ácida crítica del procedimiento legal inglés, esbozando lineamientos compartidos con su amigo Bentham. Sobre la astronomía, después de una detallada disquisición, concluye que en el mejor de los casos "el mundo oriental ha hecho, en cierta medida, el mismo progreso que el mundo occidental ha llevado a un nivel de perfección más elevado". Y relaciona otras aparentes generalidades, como la habilidad para tejer, la "precisión en la imitación" y cierta delicadeza del trato con una supuesta vocación hacia el servilismo. "En verdad, el hindú, como el eunuco, es excelente en las cualidades de un esclavo" (lib. III, cap. V).

En el momento oportuno explicitó: "La cuestión es, por lo tanto, si [con el cambio de gobierno] [...] la población hindú de la India ganó o perdió" (ibíd.). Pero con una mezcla de diplomacia y eficacia evitó una comparación inmediata con la administración británica, poniendo en el foco en cambio a los conquistadores anteriores. Concluyó que "en la situación encontrada por los Mahometanos en la India, todo testimonia contra la ficción de una gran monarquía, de una gran prosperidad y de una gran civilización" (lib. II, cap. X, nota 63). "En casi todos los aspectos, una decidida superioridad estaba en el lado de los invasores".

Destacó, en particular, un avance en "las artes del gobierno", con procedimientos y funciones más eficientes; la introducción de moderación y certidumbre en el sistema tributario, en contraste con la arbitrariedad y los abusos de los príncipes hindúes; una mayor responsabilidad social, con mejoras específicas en las obras públicas y la asistencia social, pues el "egoísmo, destructivo de la virtud privada y pública, era universal en Indostán” (lib. III, cap. IV), y una flexibilización de la tiranía sobre los individuos, pues la integración musulmana entre religión y gobierno jamás habría alcanzado "la máxima subyugación conocida en el mundo", atribuible a los privilegios inamovibles de los brahmanes, combinados con una "superstición milenaria" y con el despotismo nativo.

Sobre todo, "Un sistema de maneras como el mahometano, basado en el supuesto de una igualdad natural de los seres humanos”, permitía el ascenso de los individuos desde las posiciones más humildes hasta las más exaltadas, de acuerdo con los méritos y las funciones; en contraste con el "detestable" sistema de castas que, con sus extremas injusticias e ineficiencias, condenaba a los seres humanos a una suerte irremisible. Sentenció, por consiguiente: "La naturaleza humana en la India ganó, y ganó muy considerablemente, pasando de un gobierno hindú a uno mahometano" (lib. III, cap. V). 
Parecería, entonces, que sugiere dos implicaciones: una nación se podría beneficiar con la invasión y la conquista violenta por parte de otra, y esto se aplicaría con mayor razón a la dominación británica dado que, según el "ranking”, concepto literal de Mill en su etnografía comparativa, los europeos occidentales ocupaban el máximo nivel.

\section{PRECISIONES CONTRA LOS INDICIOS}

Primera: La capacidad para un mejor gobierno no lo garantiza. En 1799, la fuerza desproporcionada de tres ejércitos británicos, con otro ejército nativo, se lanzó sobre el "pequeño príncipe" de Mysore, el Sultán Typoo, con el pretexto de la seguridad. Mill señaló: "La palabra seguridad [...] estaba calculada para responder a cualquier propósito [...] Las demandas de seguridad no tenían límite, excepto el placer y el poder de quienes las establecían" (lib. VI, cap. VIII). Y, al respecto, sintetizó casi medio siglo de dominación británica así: "E1 sultán tenía el discernimiento para percibir que es la prosperidad de quienes trabajan con sus manos lo que constituye el principio y la causa de la prosperidad de los Estados, algo generalmente oculto ante los ojos de los gobernantes en etapas más ilustradas de la sociedad; por tanto [...] al menos durante la primera y mejor parte de su reinado, su país era el mejor cultivado y su población la más floreciente en la India; mientras que, precipitándose a un estado desértico, bajo los ingleses y sus subalternos la población de Carnatic y de Oude era la más desgraciada sobre la faz de la tierra; y aun Bengala misma, bajo la operación de leyes mal adaptadas a las circunstancias del caso, estaba sufriendo casi todos los males que el peor de los gobiernos podría infligir" (ibíd.).

La situación en Bengala se debía no sólo a ignorancia de las condiciones locales, o a la rapiña personal de los funcionarios, sino a la depresión del producto nativo y a la concentración del gobierno en reformas para maximizar sus rentas territoriales, arruinando a "la mayoría de los individuos que alguna vez tuvieron rango y fortuna”, subvirtiendo las formas de subsistencia y dejando inermes a las personas ante una masiva delincuencia. Las atrocidades de las bandas de decoits, con su frecuencia, amplitud e impunidad, condujeron a Mill a usar la expresión decoity para describir una endemia social. Añadió que el ejército británico en Bengala tenía poderío de sobra para exterminar a la totalidad de la población, si hubiese querido, pero en cambio el gobierno declaraba su incapacidad para financiar la administración de justicia; lo cual tomó como un indicador del peor gobierno posible en cualquier tiempo o lugar (lib. VI, cap. VI). 
Pero refiriéndose a la situación de decenios atrás, cuando regresó a su segunda gobernación, Clive mismo había reconocido: "En Calcuta [...] treinta millones de seres humanos fueron reducidos al extremo más miserable [...] difícilmente compatible con la existencia misma de la sociedad" (citado por Adams, 1896, 252).

En Carnatic y Oude, "Las opresiones de los gobiernos nativos estaban limitadas por sus debilidades. Pero cuando recibieron el uso del poderío inglés sus opresiones quedaron limitadas por nada, excepto la capacidad física del pueblo para sobrevivir bajo la opresión" (lib. VI, cap. VII). De manera explícita, el artículo 17 del Tratado de Bassein, firmado en 1802 con el Peshwa de los maharattas establecía: "La fuerza subsidiaria [británica] estará disponible en todo momento para tales servicios como la debida corrección de los súbditos y subalternos de su Majestad, o la persecución y castigo de los rebeldes o agitadores" (citado en lib. VI, cap. XI). Con oportunidad de estos casos, Mill expuso en general una circulación de las élites con dos componentes: la degeneración sucesiva de los herederos del poder, en términos de las cualidades para preservarlo; y la tendencia a acrecentar "la opresión produce declinación de los ingresos", merma tributaria, crisis del endeudamiento público, organización de los descontentos, involucrando intervenciones de poderes vecinos, debilitamiento del régimen y finalmente su relevo. (Más de un siglo después, la circulación de las élites en la versión de Pareto tendería a reducirse al primer componente). Concluye Mill, por lo tanto, que en la India, después de dos o tres generaciones en el poder, "la revolución" (el derrocamiento y sustitución del régimen) era el mecanismo para el control del mal gobierno y para las correcciones recurrentes, lo cual dejó de funcionar con el arribo del poderío británico.

"La fuente de casi todas las opresiones [...] es el apetito desaforado para exprimir más y más rentas del pueblo. En vez de moderarse, esta pasión es prodigiosamente inflamada por la conexión con los ingleses, cuando el príncipe tributario es llevado a todos los excesos en los impuestos, no sólo por su propia rapacidad, sino por la necesidad de satisfacer las enormes demandas de sus amos europeos; y cuando sus soldados, así como su pueblo, son tenidos en una sumisión abyecta y sin esperanza mediante el terror de las armas europeas [...] El aumento progresivo de esta opresión produjo una resolución británica para la reforma únicamente cuando la visible desolación del país presentaba la rápida aproximación al momento en que sería imposible encontrar fuentes para el subsidio obtenido por los ingleses" (lib. VI, cap. VII).

Además, las reformas de 1790 sobre la tenencia de la tierra habrían constituido uno de los errores más graves pues, buscando la creación 
"artificial" de una aristocracia análoga a la inglesa, se otorgaron los títulos y los incentivos a los antiguos recaudadores (zemindars), en vez de concederlos a los productores directos (ryots); mientras la propiedad y la libertad para estos serían las claves en el aumento de la riqueza y de las rentas. Por consiguiente, concluyó que para el progreso humano "se perdió en la India una oportunidad sin paralelos en la historia mundial” (lib. VI, cap. V).

En dicho fracaso se destacaron: por una parte, la debacle del sistema judicial, pues "mientras los zemindars tienen poder para explotar a los ryots, estos pueden demandarlos", sin atisbos de solución alguna para decenas de miles de pleitistas durante sus vidas; $y$, por otra parte, "los prejuicios de la aristocracia", pues a pesar de su propiedad territorial, no gracias a esta, el progreso de la agricultura inglesa habría sido posible. A propósito, añadió: "Bajo la influencia del vulgar error de que el Ego sería excelente [...] las instituciones inglesas y las prácticas inglesas han sido generalmente establecidas como un estándar, en conformidad o desconformidad con el cual sería determinada la excelencia o el defecto de todas las cosas en el mundo" (lib. VI, cap. VI).

Segunda: Otras opciones de transferencia. En un discurso ante el Parlamento, en 1793, el primer ministro británico afirmó que sin el monopolio de la Compañía se impondría el libre comercio con la India, lo cual implicaría una colonización (en el sentido filial de Smith) y, a su vez, esto desencadenaría la independencia, como en Norteamérica. Mill señaló, entonces, que en el fondo se encontraba el temor a la pérdida de las rentas territoriales; y a la pérdida de la "masa de riqueza equivalente a todos los cargos lucrativos" de la India, habría que añadir de acuerdo con su previo análisis. Por lo tanto, con base en el temor, el monopolio y el enclave colonial, repudiando cualquier integración con la población nativa, se aplicaba una "política iliberal, cobarde y miope, bajo la cual se toman las precauciones más solícitas para prevenir el establecimiento de pobladores ingleses en la India" (lib. VI, cap. VI).

Un agravante era el desarraigo y la rotación de los funcionarios británicos, quienes después de amasar rápidas fortunas sólo pensaban en regresar a su país, precisamente cuando habían adquirido algún conocimiento local. No sorprende, entonces, que Mill destacara el contraste con el dominio musulmán, al cual calificó como "un gobierno nativo".

En consecuencia, "Estamos impedidos para estudiar el carácter del pueblo en su propia esfera de acción. Sabemos poco de su vida 
doméstica; de sus conocimientos, de su conversación, de sus oficios y castas, o de las características individuales y nacionales que son esenciales para conocerlos de manera integral [...] Carecemos de guía en la investigación de los hechos, excepto la extrema incertidumbre de nuestra propia opinión y la conciencia de nuestra incapacidad para juzgar lo que es probable o improbable [...] El daño del cual me quejo es extensivo y temo que irreparable" (Sir Henry Strachey, Juez superior en la India hacia 1800, citado en lib. VI, cap. VI).

Lógicamente, Mill concluyó que un buen gobierno resultaba imposible en tales condiciones, sobre lo cual sostuvo su defensa de la libertad de comercio y de poblamiento. Pero su tesis sobre la imposibilidad de transferirle lo mejor a un pueblo sin conocerlo y sin su propia participación proyectaba un alcance general: "Después de los efectos de mejores leyes sobre el carácter intelectual y moral de los nativos, estaría la difusión de la población inglesa en la sociedad nativa por medio de la colonización, de la cual, como hemos visto, tantas consecuencias importantes fluirían” (ibíd.).

Señaló un último obstáculo para dicha opción: "Desafortunadamente es casi imposible establecer un número considerable de europeos en la India; porque los nativos subsisten con tan poco que los salarios de los trabajadores son demasiado bajos para permitirles vivir a los europeos. Si fuese posible nada resultaría tan ventajoso [como este poblamiento] para los dos pueblos, de la India y de Inglaterra" (lib. VI, cap. VII).

Sin embargo, también observó que en la India "hay todavía una prodigiosa cantidad de tierras de buena calidad sin cultivar", coincidentes con "el inestimable servicio que podría derivarse [...] de un cuerpo de caballeros ingleses [...] si hubieran sido estimulados a establecerse como propietarios de tierras, y como industriales, y como comerciantes" (lib. VI, cap. VI).

Tercera: la evaluación financiera de la guerra arrojaría resultados similares en el gobierno. Dada una tasa de interés en Londres del 5\%, Mill encontró que el valor presente neto de la conquista era negativo para Inglaterra, con horizonte en 1805, cuando termina su Historia; aunque pudo habérsele argumentado que ignoró los escenarios sobre flujos de costos y beneficios futuros.

Mientras tanto, en la India las tasas de interés podían situarse en niveles exorbitantes, aun para reconocidos rentistas agrícolas; y la tasa preferencial más baja, para deudores como la Compañía, era del 9\%. ("En Bengala es frecuente que se preste el dinero a los granjeros al 40, 50 y 60\%, hipotecando para el pago la cosecha venidera”: Smith, 
1776, lib. I, cap. IX). Utilizando para el grueso de los indios una tasa del 10\%, en gracia de discusión, cualquier beneficio habría perdido el 99\% de su valor presente después de 48 años y el 99,9\% después de 70 años. Por tanto, aun enormes beneficios futuros parecerían incapaces de compensar el sacrificio de las primeras generaciones, incluso si estas lo hubiesen asumido con la racionalidad de un proyecto.

Claro está, un argumento sobre la impertinencia de las tasas de descuento en términos de distribuciones intergeneracionales podría dar lugar a diversas opiniones, incluso a reforzar la conclusión de Mill con el horizonte utilizado para el caso de Inglaterra; así como a privilegiar los derechos fundamentales de las víctimas para el caso de la India.

Cuarta: externalidades en la lista de beneficios y costos. Una evaluación exhaustiva involucraría elementos como los siguientes. En sus memorias de la campaña en Mysore, el Teniente Moore, del ejército británico, anotó: "Los habitantes de los Estados conquistados se sometían con aparente resignación a la dirección de sus conquistadores [ingleses], pero [...] tan pronto se ofrecía una oportunidad, burlaban a sus nuevos amos y gustosamente volvían otra vez a su anterior lealtad" (citado en lib. VI, cap. IV, nota 19). "La familia del rajá [de Benarés] era naturalmente querida [por la población]; y de la documentación citada por el gobernador, parece suficientemente que en estas regiones los ingleses eran detestados de manera muy especial" (lib. V, cap. VII). "Maravilla ver cómo, a cada momento y voluntariamente, el gobierno inglés (en la India) se coloca en la condición de un gobierno opuesto al pueblo; un gobierno que odia al pueblo, porque le teme, y a su vez es odiado por el pueblo" (lib. VI, cap. VI, nota 71).

Quinta: aun el mejor gobierno carece de soberanía universal. Sobre la orden para derrocar al nabab de Surat en 1800 porque, en palabras del gobernador británico, el buen gobierno "sólo puede lograrse si la totalidad del gobierno militar y civil es tomada por la Compañía", Mill señaló: "Otra vez vemos aquí claramente declarada y con toda confianza expuesta, como base de acción, la doctrina de que el mal gobierno bajo cualquier soberano genera un derecho, y aun un deber, para destronarlo; en favor únicamente de la Compañía de las Indias Orientales, si resulta que ésta posee el monopolio del derrocamiento; o en favor de la humanidad en general, si el privilegio resulta tan difuso como la razón en que se fundamenta" (lib. VI, cap. X).

Anotó que cuando "el pueblo [invadido] no tiene voz sobre la materia", las naciones invasoras o sus gobernantes actúan "con miras a sus propios beneficios”y, con ocasión de las acciones británicas para 
dividir a los maharattas, en 1802, negociando con el Peshwa la máscara de un gobierno autóctono en el residuo de región que le quedaba, añadió: "Si admitimos que el gobierno inglés haría un mejor uso del nuevo poder que un gobierno nativo, y sería una desgracia pensar lo contrario, el argumento [sobre el derecho británico para sustituir a los malos gobiernos] iría mucho más lejos de lo que el gobernador desearía; pues entonces ningún gobierno nativo debería quedar en la India" (lib. VI, cap. XI).

Este último escenario terminaría imponiéndose, una pieza de dominó tras otra, provincia por provincia; pero, como describe Mill en su último capítulo, con los británicos forzados en 1805 a negociar una paz con todas las concesiones para los maharattas, la tesis resultaba autodestructiva aplicada de manera simultánea. En general, en su plena consecuencia el argumento sobre el derecho de sustitución implicaba que ningún gobierno nativo debería quedar en el globo, excepto el de la nación "superior" en el ranking universal, nutriendo ideologías que luego conducirían a su propio cataclismo mundial.

Y advirtió: "Aun donde la disparidad de civilización y conocimiento fuese muy grande, y donde sin discusión alguna un país civilizado fuese a llevar a otro país bárbaro uno de los mayores beneficios posibles, un buen gobierno y además benevolente, aun en ese caso se requerirían las circunstancias más extremas para justificar el empleo de la violencia o la fuerza [...] La imposición sobre una nación, por la fuerza de ejércitos extranjeros, y por el placer o el interés de gobernantes extranjeros [...] sella con infamia el más notable quizá de todos los crímenes que pueden ser cometidos contra la naturaleza humana" (ibíd.).

\section{EL ANÁLISIS, EL AUTOR Y LA COMPAÑía}

Sin embargo, en un giro paradójico, también declaró Mill: “En tanto los sentimientos de millones son de más valor que los de un individuo [el nabab] [...] deberíamos encontrar justificada a la Compañía en la toma del gobierno de Carnatic desde mucho antes; y bajo el mismo principio deberíamos regocijarnos de que cada pulgada de suelo dentro de los límites de la India estuviese sujeta a su dominio [...] En asuntos de detalle, he tenido la ocasión de culpar con más frecuencia que de elogiar al gobierno de la Compañía [...] Sin embargo, creo que se concluirá que, durante el período de su soberanía, la Compañía ha hecho más en beneficio de sus gobernados, ha mostrado mejores intenciones hacia ellos, ha mostrado una fijación menos egoísta hacia los perversos instrumentos de poder en sus manos y ha desplegado una bienvenida más generosa a los planes de mejoramiento, no sólo 
en comparación con cualquier otro soberano existente en el mismo período, sino en comparación con todos los demás soberanos sobre la faz de la tierra tomados en su conjunto" (lib. VI, cap. X).

Claro está, el acotamiento de las actuaciones de la Compañía "durante el período de su soberanía" abstrae los costos antecedentes, y sobre este hecho cumplido se refiere sólo a las posibilidades futuras de mejoramiento, a las cuales Mill mismo contribuiría, tal vez en forma significativa. De manera similar, "los sentimientos de millones" nunca fueron consultados con respecto a los ingleses, o con respecto a los franceses, o con respecto a otras alternativas, incluyendo opciones indias distintas de algún nabab.

De otro lado, la más acerba crítica exigiría señalar, quizá, que la situación de Mill terminó incluida dentro de la "masa de riqueza equivalente a todos los cargos lucrativos" derivados de la dominación sobre la India, pues la primera edición de La historia salió en 1818, después de doce años de dedicación, mientras que a comienzos de 1819 Mill ingresó como funcionario de la Compañía en Londres, "quedando asegurado finalmente su futuro financiero", en las palabras de un biógrafo. Por ejemplo, en una reseña de ensayos de Pitts, Rosen y Majeed sobre el utilitarismo y el imperio, Peers (2006) se pregunta si un contraste con Bentham implicaría que, debido a sus posiciones en la Compañía de las Indias Orientales, James y John Stuart Mill fueron más tolerantes con el discurso imperialista y etnocentrista.

Es evidente que los ensayos de Bentham sobre las posesiones coloniales, la guerra y la paz contradicen radicalmente dicho discurso. (Por el momento basta esta observación: "Mi análisis parece satisfactorio con respecto a las siguientes proposiciones. I. Que la posesión de dependencias extranjeras es ajena por completo a los intereses de Gran Bretaña”, Bentham, 1789, Ensayo 4). Pero parece igualmente cierto que el problema fundamental con la paradójica declaración de Mill consiste en la incoherencia ante su propio análisis, como pudo verse en la sección anterior.

Es más, en 1825, en su artículo "Colonias", para la Enciclopedia Británica, reafirmó y elevó a tesis general su posición en contra de la dominación internacional, como un beneficio para la minoría gobernante a expensas de la mayoría en la metrópolis porque: a) una situación de guerra sirve como pretexto para disminuir los controles democráticos sobre los gobernantes; b) mediante tal combinación, estos se lucran en honores, poder, gasto, masa de cargos e influencias, y c) los costos corren a cargo de las mayorías. 
Sin embargo, con una retrospectiva menos optimista, en el análisis detallado de La historia, los beneficios extraídos por la dominación internacional pueden ser irrigados sobre amplias capas de la población metropolitana, sin límite teórico alguno para su cobertura (incluso total), sobre todo en términos de expectativas y de oportunidades, excepto la cota establecida por la magnitud misma de los beneficios esperados.

\section{REFERENCIAS BIBLIOGRÁFICAS}

1. Adams, B. The law of civilization and decay, 1896, New York, Vintage Books, 1943.

2. Bentham, J. Principles of international law, 1789, Bowring Edition, 1843 [http://www.laits.utexas.edu/poltheory/bentham/pil/index.html].

3. Heckscher. E. La época mercantilista, 1931, México, Fondo de Cultura Económica, 1983.

4. Keegan, J. A history of warfare, 1993, New York, Vintage Books, 1994.

5. Mill, J. The history of British India, London, Baldwin, Cradock, and Joy, 1826.

6. Mill, J. "Government", Encyclopedia Britannica, 1820 [http://studymore. org.uk/xmilgov.htm].

7. Mill, J. Elements of political economy, 1821, London, Henry G. Bohn, 1844 [http://www.econlib.org/library/Milljames/mljElm.html].

8. Mill, J. "Colony", Encyclopedia Britannica, 1825.

9. Peers, D. "Utilitarianism and Empire (Review)", Victorian Studies 49, 1, 2006, pp. 151-153.

10. Smith, A. Investigación sobre la naturaleza y causas de la riqueza de las naciones [1776], México, Fondo de Cultura Económica, 1958.

11. Strachey, J. El fin del imperio, 1959, México, Fondo de Cultura Económica, 1974.

12. Tschöpe, R. "Verenigde Oost-Indische Compagnie", 2008 [www. oldestshare.com]. 